\title{
Method Validation for Multi-Elemental Analysis of Dialyzable and Non-dialyzable Fractions of Coffee Brews by F AAS and ICP OES: a Bioaccessibility Study
}

\author{
Anna Szymczycha-Madeja ${ }^{1} \cdot$ Maja Welna $^{1} \cdot$ Pawel Pohl $^{1}$
}

Received: 6 May 2018 / Accepted: 3 September 2018 / Published online: 10 September 2018

(C) The Author(s) 2018

\begin{abstract}
A simple and fast, non-digestion treatment, and fully validated preparation procedures of dialyzable and non-dialyzable fractions of brews of ground (GCs) and instant (ICs) coffees prior to their elemental analysis (Al, $\mathrm{Ba}, \mathrm{Ca}, \mathrm{Cr}, \mathrm{Cu}, \mathrm{Fe}, \mathrm{Mg}, \mathrm{Mn}, \mathrm{Ni}, \mathrm{Sr}, \mathrm{and}$ $\mathrm{Zn}$ ) by flame atomic absorption spectrometry (F AAS) and inductively coupled plasma optical emission spectrometry (ICP OES) was developed. Three different procedures: wet digestions (P1), direct analysis (P2), and acidification with $\mathrm{HNO}_{3}(\mathrm{P} 3)$ were tested. Among tested procedures, the direct analysis (P2) gave the most satisfactory results, i.e., precision from $0.54 \%$ (Fe) to $5.9 \%(\mathrm{Cu})$, recoveries ranging between $98.0 \%(\mathrm{Sr})$ and $104 \%(\mathrm{Al})$, detection limits within $0.095(\mathrm{Ba})-1.8(\mathrm{Ni}) \mu \mathrm{g} \mathrm{L}^{-1}$, and quantification limits from $0.32(\mathrm{Ba})$ to $6.0(\mathrm{Ni}) \mu \mathrm{g} \mathrm{L}{ }^{-1}$. The chosen procedure was applied to determine bioaccessibility of 11 elements in GCs and ICs coffees using in vitro gastrointestinal digestion. Average contributions of the bioaccessible fraction (\%) of elements in brews were as follows: $\mathrm{Al}(19.0,23.0), \mathrm{Ba}(42.8,48.4), \mathrm{Ca}(35.0,38.9), \mathrm{Cr}(<\mathrm{LOD}, 31.1), \mathrm{Cu}(15.0,14.3), \mathrm{Fe}$ (5.08, 2.81), Mg (32.2, 37.9), Mn (28.1, 29.1), Ni (40.9, 60.0), Sr (43.2, 45.6), and Zn (11.5, 9.57) for GCs and ICs coffees, respectively. Generally, bioaccessibility of most elements, i.e., $\mathrm{Al}, \mathrm{Ba}, \mathrm{Ca}, \mathrm{Cu}, \mathrm{Mg}, \mathrm{Mn}, \mathrm{Ni}$, and $\mathrm{Sr}$ in brews of GCs was lower than this determined in ICs and varied from 4\% (Mn) to $47 \%(\mathrm{Ni})$. In contrast, higher contributions of the bioaccessible fraction of Fe and $\mathrm{Zn}$ were assessed for GCs brews (47\% and 17\%, respectively), than these evaluated in ICs brews. Additionally, results on total concentrations of elements in brews of GCs and ICs and concentrations of elements in the dialyzable fraction separated from these brews were applicable to differentiate and classify all analyzed coffees by principal component analysis (PCA).
\end{abstract}

Keywords Coffee brews $\cdot$ Method validation $\cdot$ In vitro gastrointestinal digestion $\cdot$ F AAS $\cdot$ ICP OES $\cdot$ Statistical analysis

\section{Introduction}

Today, coffee brewed from ground roasted coffee (GC) beans or prepared directly from soluble (instant) coffee (IC) powders is one of the most consumed beverage in the world. Its popularity is primarily due to unique taste, aroma as well as recognized health effects (Grembecka et al. 2007; Oliveira et al. 2012). Typically, knowledge about total concentrations of elements in food and beverages is usually used to judge their nutritional value and degrees of coverage of their daily recommended dietary intakes (RDIs). Unfortunately, such an

Anna Szymczycha-Madeja

anna.szymczycha@pwr.wroc.pl

1 Department of Analytical Chemistry and Chemical Metallurgy, Faculty of Chemistry, Wroclaw University of Technology, Smoluchowskiego 23, 50-372 Wroclaw, Poland approach is not entirely justified. Although information on the total content of elements in brewed coffees can be applied to assess their quality and safety or to differentiate these products, in fact, it does not provide any estimation about functionality and bioaccessibility of elements from coffee brews. Actually, to consider the uptake of elements from food and their role in human nutrition, total contents of elements fail and mechanisms of their intake from the gastrointestinal tract during consumption should be taken into account. Therefore, estimation of bioaccessibility of elements is important and can be performed by in vivo and/or in vitro methods. Unfortunately, human and animal in vivo studies are expensive, laborious, difficult, require specific infrastructure, and are often limited from an ethical point of view. In contrast, in vitro experiments are much more simple, faster, and cheaper, hence are a good alternative to in vivo studies. Accordingly, bioaccessibility of elements evaluated through the in vitro assay under conditions simulating physiology of the stomach and intestines can give the answer about dietary 
aspects of elements included in consumed food and beverages (Hur et al. 2011; Intawongse and Dean 2006).

In recent years, in vitro gastrointestinal digestion has been applied to estimate bioaccessibility of elements from various food products and beverages, including fruit juices (Cautela et al. 2009; de Lima et al. 2014; Haro-Vicente et al. 2006), infant formulas (Bermejo et al. 2002; do Nascimento da Silva et al. 2017), tea (Powell et al. 1998; Erdemir 2018), herbal infusions (Pereira Junior et al. 2018; Zhou et al. 2014), GCs and ICs (Stelmach et al. 2014, 2016), slim coffees (SzymczychaMadeja et al. 2015), chocolate drink powder (Peixoto et al. 2013), various milks (Bermejo et al. 2002; Chaiwanon et al. 2000; Shen et al. 1995), honey (Pohl et al. 2012), fruits and vegetables (do Nascimento da Silva et al. 2015; Khouzam et al. 2011; Machado et al. 2017; Oliveira et al. 2018; Pereira et al. 2016), breads (Gawlik-Dziki et al. 2009; Khouzam et al. 2011; Lamsal and Beauchemin 2015), cereals (do Nascimento da Silva et al. 2017), white cheeses (Khouzam et al. 2011), various meats (Menezes et al. 2018), and edible seaweeds (Dominguez-Gonzalez et al. 2010; García-Sartal et al. 2011, 2013). Commonly, a two-step procedure that simulates stomach and intestinal digestion with solutions of pepsin in the gastric phase and a mixture of pancreatin and bile salts in the intestinal phase is used. Gastrointestinal digestion is carried out at $37{ }^{\circ} \mathrm{C}$ (normal temperature of the human body) while incubation time (with gentle shaking mimicking gastric and intestinal peristalsis) is typically $2 \mathrm{~h}$ for each step. Gastric digestion is usually simulated using solutions of pepsin $(0.001-16 \%)$ prepared in a dilute $\mathrm{HCl}$ solution $(\mathrm{pH} 2)$. Intestinal digestion is imitated using a mixture of pancreatin $(0.015-3.04 \%)$ and bile salts $(0.15-2.8 \%)$ adjusted to $\mathrm{pH} \sim 7$ by addition of a $\mathrm{Na}_{2} \mathrm{CO}_{3}$ solution ( 0.1 or $1.0 \mathrm{~mol} \mathrm{~L}^{-1}$ ) (Hur et al. 2011; Intawongse and Dean 2006). Typically, absorption of elements in the villi is simulated by centrifugation (soluble fraction) or dialysis (dialyzable fraction). Nevertheless, dialysis of elements species across a semipermeable membrane as a model for the passage across the intestinal villi appears to be more appropriate, because results obtained in these conditions well correspond with those from in vivo studies (Ekmekcioglu 2002; Wolters et al. 1993). Finally, elements released to soluble or dialyzable fractions are determined by flame atomic absorption spectrometry (F AAS), inductively coupled plasma optical emission spectrometry (ICP OES), and inductively coupled plasma mass spectrometry (ICP-MS). Before spectrochemical analysis, resulting sample solutions can be initially prepared with the aid of open-vessel or closedvessel wet digestions (do Nascimento da Silva et al. 2015; García-Sartal et al. 2011, 2013; Peixoto et al. 2013; Souza et al. 2018) or analyzed directly, i.e., without any pre-treatment (de Lima et al. 2014; Dominguez-Gonzalez et al. 2010; do Nascimento da Silva et al. 2017; Erdemir 2018; Khouzam et al. 2011; Lamsal and Beauchemin 2015; Menezes et al. 2018; Pereira et al. 2016; Pereira Junior et al. 2018).
In view of this, the objective of this work was to develop a precise and accurate method of multi-elemental analysis of dialyzable and non-dialyzable fractions of GCs and ICs brews by F AAS and ICP OES with the least demanding sample preparation procedure. Three different treatments of sample solutions obtained after gastrointestinal digestion, including wet digestion, direct analysis, and acidification with $\mathrm{HNO}_{3}$, were tested. The selected procedure was applied to determine bioaccessibility of essential (Ca, $\mathrm{Cr}, \mathrm{Cu}, \mathrm{Fe}, \mathrm{Mg}, \mathrm{Mn}, \mathrm{Ni}, \mathrm{Zn}$ ) and non-essential (Al, Ba, Sr) elements in brews of $18 \mathrm{GCs}$ and ICs commercially available in Poland using an in vitro gastrointestinal digestion method under conditions typically applied for different food products and beverages. It must also be commented that bioaccessibility of $\mathrm{Al}, \mathrm{Ba}, \mathrm{Cr}, \mathrm{Cu}, \mathrm{Ni}, \mathrm{Sr}$, and $\mathrm{Zn}$ from brews of different GCs and ICs was evaluated in the present study for the first time. So far, only two works were devoted to evaluation of bioaccessibility of elements from brews of GCs and ICs and concerned only $\mathrm{Ca}, \mathrm{Fe}, \mathrm{Mg}$, and Mn (Stelmach et al. 2014, 2016). Finally, total concentrations of elements in brews of GCs and ICs and concentrations of elements in the dialyzable fraction separated from these brews were applied to differentiate and classify all analyzed coffees by means of principal component analysis (PCA).

\section{Experimental}

\section{Instrumentation}

A Bodenseewerk Perkin-Elmer GmbH single-beam spectrophotometer (model 1100B), equipped with a deuterium lamp for background correction, a Littrow mount, 267-mm optical length monochromator with a 1800 lines/mm grating, and a photomultiplier, were used to measure concentrations of $\mathrm{Ca}$ and $\mathrm{Mg}$ by F AAS with a fuel lean air- $\mathrm{C}_{2} \mathrm{H}_{2}$ flame. The flame was sustained in a 10-cm, Ti, single-slot burner head mounted on an inert, plastic-coated burner-mixing chamber ended with a nebulizer holder and a drainage assemblage. A selfaspirating steel nebulizer and a flow spoiler were used to introduce solutions to the burner-mixing chamber by pneumatic nebulization (PN). Operation settings recommended by the producer were applied, i.e., analytical lines, $422.7 \mathrm{~nm}(\mathrm{Ca})$ and $285.2 \mathrm{~nm}(\mathrm{Mg})$; spectral band-passes, $0.7 \mathrm{~nm}$; flow rates of gases, 8.0 (air) and $1.5 \mathrm{~L} \mathrm{~min}^{-1}$ (fuel); the burner height: $6.0 \mathrm{~mm}$; and lamp currents, $15 \mathrm{~mA}$. Averaged readings of background corrected absorbance (3 replicates), taken within $3.0 \mathrm{~s}$ in a time-average integration mode, were used for calibration. Concentration ranges for working calibration standard solution were within $0.1-5.0 \mu \mathrm{g} \mathrm{mL}^{-1}$. Five-point calibration curves were used for measurements.

An Agilent bench-top optical emission spectrometer of an axially viewed Ar-ICP, model 720, was used to determine concentrations of trace elements, i.e., $\mathrm{Al}, \mathrm{Ba}, \mathrm{Cr}, \mathrm{Cu}, \mathrm{Fe}$, 
$\mathrm{Mn}, \mathrm{Ni}, \mathrm{Sr}$, and $\mathrm{Zn}$. The instrument was equipped with a fourchannel peristaltic pump, a high-resolution echelle-type polychromator and a VistaChip II CCD detector. A standard, one-piece, low-flow, extended quartz torch with an injector tube (2.4 mm ID) was used to sustain the plasma. The torch was combined with a single-pass glass cyclonic spray chamber. A high-tech engineering polymer (PFA and PEEK) OneNeb concentric nebulizer was mounted into the spray chamber and applied to introduce solutions by PN. Operating instrument settings were as follows: the RF power, $1.2 \mathrm{~kW}$; gas flow rates, 15.0 (plasma), 1.5 (auxiliary), and $0.75 \mathrm{~L} \mathrm{~min}^{-1}$ (nebulizer); the sample flow rate, $0.75 \mathrm{~mL} \mathrm{~min}^{-1}$; stabilization and sample uptake delays, 15 and $30 \mathrm{~s}$; rinse and replicate times, 10 and $1 \mathrm{~s}$ (three replicates). Atomic (I) and ionic (II) analytical lines selected for measurements were as follows: Al I $396.2 \mathrm{~nm}$, Ba II $455.4 \mathrm{~nm}$, Cr 267.7 nm, Cu I 324.8 nm, Fe 259.9 nm, Mn II 257.6 nm, Ni II $231.6 \mathrm{~nm}$, Sr II $407.8 \mathrm{~nm}$, and Zn I $213.8 \mathrm{~nm}$. Concentration ranges for working calibration standard solution were within $0.1-5.0 \mu \mathrm{g} \mathrm{mL}^{-1}$. Five-point calibration curves were used for quantification. A fitted background mode with seven points per line profile was applied for background correction (FBC). Background corrected intensities of analytical lines were used for calibration.

A MPW-350 centrifuge (MPW Medical Instruments, Poland) was used to separate any particles from brews of ICs. An Elpin (Katowice, Poland) thermostatic water bath shaker (type 357) was used in incubation experiments. A high-retention cellulose dialysis tubing with molecular weight cutoff (MWCO) of $12.4 \mathrm{kDa}$ (Sigma-Aldrich Chemie GmbH, Steinheim, Germany) was used to separate the bioaccessible fraction of studied elements from incubates of brews of analyzed GCs and ICs. A DigiPREP Jr digestion block (SCP SCIENCE, Canada) with a touch screen controller was used to digest dialyzable and non-dialyzable (residual) fractions of coffee brews in a concentrated $\mathrm{HNO}_{3}$ solution.

\section{Reagents and Samples}

EMSURE ${ }^{\circledR}$ ACS grade reagents, i.e., concentrated $\mathrm{HNO}_{3}$ $(65 \%, \mathrm{~m} / \mathrm{v})$ and $\mathrm{HCl}(37 \%, \mathrm{~m} / \mathrm{v})$ solutions, were purchased from Merck Millipore (Germany). Pepsin from porcine gastric mucosa (800-2500 units $\mathrm{mg}^{-1}$ of protein), pancreatin from porcine pancrease, bile salts, PIPES ((piperazine-NN-bis(2ethane-sulfonic acid) disodium salt)), $\mathrm{NaCl}$ and $\mathrm{NaHCO}_{3}$ were provided by Sigma-Aldrich. Freshly prepared solutions of simulated gastric (SGJ) and intestinal (SIJ) juices were used in experiments. De-ionized water from an EASYpure ${ }^{\mathrm{TM}}$ water purification system (Barnstead Corp., USA) was used throughout. A Merck Certipur ${ }^{\circledR}$ multi-elemental stock (1000 $\mathrm{mg} \mathrm{L}^{-1}$ ) ICP standard solution IV was used to prepare simple and matrix-matched standard solutions for calibration of F AAS and ICP OES instruments.
Eight regular commercial samples of GCs (GC1-GC8) and their eight instant equivalents (ICs, IC1-IC8), sold under the same names, were purchased in a discount supermarket belonging to a global chain in Poland and other EU countries. Additionally, two ICs with admixtures of GC powders were selected, i.e., IC9 and IC10.

\section{Sample Preparation}

\section{Coffee Brewing}

To prepare brews of GCs, samples $(6.0 \mathrm{~g})$ as received (milling excluded) were placed in 400-mL glass beakers, poured with $200 \mathrm{~mL}$ of boiling $\left(100^{\circ} \mathrm{C}\right)$ de-ionized water and left at room temperature $\left(22 \pm 1^{\circ} \mathrm{C}\right)$ under the cover to brew for $10 \mathrm{~min}$. Resulting brews were separated from settled grounds by filtering them through 390 grade quantitative filterpapers (Munktell \& Filtrak, Germany). In case of brews of ICs, samples $(6.0 \mathrm{~g})$ as received (milling excluded) were placed in 400 $\mathrm{mL}$ glass beakers, poured with $250 \mathrm{~mL}$ of hot water $(90$ $95^{\circ} \mathrm{C}$ ) and dissolved by mixing with a glass rod. Portions of resulting brews were placed into 30-mL polypropylene (PP) centrifuge tubes and centrifuged for $10 \mathrm{~min}$ at $12000 \mathrm{rpm}$. Supernatants were separated using polyethylene (PE) syringes. Collected filtrates (GCs) and supernatants (ICs) were split and then one part was analyzed by F AAS and ICP OES for total concentrations of elements, while another part was subjected to in vitro gastrointestinal digestion.

\section{In Vitro Gastrointestinal Digestion Procedure}

Portions of GCs and ICs brews $(20 \mathrm{~mL})$ were placed in $50-\mathrm{mL}$ $\mathrm{PP}$ capped tubs and adjusted to $\mathrm{pH} 2$ with a $6.0 \mathrm{~mol} \mathrm{~L}^{-1} \mathrm{HCl}$ solution. Then, $3.0 \mathrm{~mL}$ of a SGJ solution $[0.32 \%(\mathrm{~m} / \mathrm{v})$ pepsine with $0.20 \%(\mathrm{~m} / \mathrm{v}) \mathrm{NaCl}$ dissolved in $0.08 \mathrm{~mol} \mathrm{~L}^{-1}$ $\mathrm{HCl}$ ] was added to simulate gastric digestion. Samples were incubated in a temperature-controlled shaking water bath at $37{ }^{\circ} \mathrm{C}$ with agitation $(150 \mathrm{rpm})$ for $2 \mathrm{~h}$. Enzymatic reaction was stopped by placing the tubes into an ice-bath for $10 \mathrm{~min}$. Then, $5.0 \mathrm{~mL}$ of a SIJ solution $[0.40 \%(\mathrm{~m} / \mathrm{v})$ pancreatine and $2.5 \%(\mathrm{~m} / \mathrm{v})$ bile salts dissolved in $0.10 \mathrm{~mol} \mathrm{~L}^{-1} \mathrm{NaHCO}_{3}$ ] was added to simulate intestinal digestion. Dialysis membrane tubings, filled with $20 \mathrm{~mL}$ of a $0.15 \mathrm{~mol} \mathrm{~L}^{-1}$ PIPES solution ( $\mathrm{pH} 7.5$ adjusted with $\mathrm{HCl}$ ) were placed inside the tubes and incubation was continued for next $2 \mathrm{~h}$ at $37^{\circ} \mathrm{C}$ with agitation (150 rpm). Finally, enzymatic reaction was stopped again by immersing the tubes in the ice-bath for $10 \mathrm{~min}$. At the end of this step, contents of dialysis membrane tubings (named dialyzate, the dialyzable fraction, or the bioaccessible fraction) and residual solutions of tubes (named non-dialyzate, the non-dialyzable fraction, or the residue) were transferred to PP vials and weighed separately. 


\section{Sample Treatment and Analysis}

Total concentrations of examined elements in brews of GCs and ICs were determined using the method developed and validated in our earlier study and comprising the simple and fast sample preparation procedure of brews (SzymczychaMadeja et al. 2016).

Three different procedures (P1-P3) were used to prepare dialyzable and non-dialyzable (residual) fractions of coffee brews prior to their elemental analysis by F AAS and ICP OES. All experiments were carried out using brews of two selected coffees, i.e., GC2 and IC2. The following procedures were tested:

Wet digestion (P1): portions of dialyzable and nondialyzable fractions of coffee brews $(5.0 \mathrm{~g})$ were weighted into 50-mL PP digestion tubes, treated with $4 \mathrm{~mL}$ of concentrated $\mathrm{HNO}_{3}$ and placed in a digestion block. Tubes were covered with PP watch glasses and heated at $100{ }^{\circ} \mathrm{C}$ for $2 \mathrm{~h}$. After cooling, clear solutions were diluted with water to $25.0 \mathrm{~g}$.

Direct analysis (P2): portions of dialyzable and nondialyzable fractions of coffee brews $(5.0 \mathrm{~g})$ were directly analyzed without any initial treatment.

Acidification with $\mathrm{HNO}_{3}$ (P3): $5.0 \mathrm{~g}$ portions of dialyzable and non-dialyzable fractions of coffee brews were placed into $10-\mathrm{mL}$ PP tubes and acidified to concentration of $0.25 \mathrm{~mol} \mathrm{~L}^{-1}$ by concentrated $\mathrm{HNO}_{3}$.All sample solutions were prepared and analyzed in triplicate $(n=3)$. In addition, respective procedural/reagent blanks were prepared and considered in final results. In case of determination of $\mathrm{Al}, \mathrm{Ba}, \mathrm{Cr}, \mathrm{Cu}, \mathrm{Fe}$, $\mathrm{Mn}, \mathrm{Ni}, \mathrm{Sr}$, and $\mathrm{Zn}$ by ICP OES, undiluted sample solutions were measured versus matrix-matched standard solutions. The latter standard solutions contained appropriate amounts of reagents subjected to given sample preparation procedure (blank samples were used). In case of determination of $\mathrm{Ca}$ and $\mathrm{Mg}$ by F AAS, sample solutions were appropriately diluted $(\times 25$ times) and analyzed against simple aqueous standard solutions as well. The dilution was made to fit the concentration of measured elements within the linearity range of calibration curves $\left(0.2-5.0 \mu \mathrm{g} \mathrm{mL}^{-1}\right)$.

\section{Principle Component Analysis}

For the purpose of data exploration and visualization, total concentrations of $\mathrm{Al}, \mathrm{Ba}, \mathrm{Ca}, \mathrm{Cr}, \mathrm{Cu}, \mathrm{Fe}, \mathrm{Mg}, \mathrm{Mn}, \mathrm{Ni}, \mathrm{Sr}$, and $\mathrm{Zn}$ determined in GCs and ICs brews were used as variables for non-supervised multivariate PCA. A PCA model was constructed for all samples. In case of $\mathrm{Cr}$ and $\mathrm{Ni}$, values of respective LODs, i.e., 0.14 and $1.8 \mu \mathrm{g} \mathrm{L}^{-1}$, were taken for some samples because they did not contain these elements. All data were standardized and used to build the Pearson ( $n$ ) correlation matrix. Two principle components (PCs) were extracted.

\section{Results and Discussion}

To assess contributions of bioaccessibility of $\mathrm{Al}, \mathrm{Ba}, \mathrm{Ca}, \mathrm{Cr}$, $\mathrm{Cu}, \mathrm{Fe}, \mathrm{Mg}, \mathrm{Mn}, \mathrm{Ni}, \mathrm{Sr}$, and $\mathrm{Zn}$, brews of GCs and ICs were subjected to gastrointestinal digestion taking into account in vitro protocols reported by other researchers for different food samples (Bermejo et al. 2002; Camara et al. 2005; Chaiwanon et al. 2000; de Lima et al. 2014; García-Sartal et al. 2011; Gawlik-Dziki et al. 2009; Pohl et al. 2012; Romarís-Hortas et al. 2011; Shen et al. 1995; Zhou et al. 2014).

Because coffee is consumed as a fluid, which is not broken down in the oral cavity and rapidly passes to a stomach, it was decided to omit any simulation of digestion in the mouth by saliva, as proposed by Cautela et al. (2009) in the case of fruit juices.

To obtain physiological $\mathrm{pH}$ (7.0), a PIPES buffer solution was used instead of a $\mathrm{NaHCO}_{3}$ solution. The first buffer solution is recognized to keep physiological $\mathrm{pH}$ during intestinal digestion because its buffering capacity is independent of temperature and the concentration of samples. Therefore, it was not necessary to perform acid-base titration of gastric digests to determine required amounts of PIPES needed to be added at the end of the simulated gastric digestion process to ensure their $\mathrm{pH}$ 7.0. Generally, the use of the PIPES buffer solution is acknowledged to improve reproducibility of in vitro digestion conditions (Dominguez-Gonzalez et al. 2010; Haro-Vicente et al. 2006).

To obtain accurate and reliable results of the bioaccessibility in vitro assay, related to determination of concentrations of elements in solutions obtained after enzymatic digestion of coffee brews by means of F AAS and ICP OES, three different sample preparation procedures of these solutions, i.e., wet digestions (P1), direct analysis (P2) and acidification with $\mathrm{HNO}_{3}$ (P3), were compared and validated. It must be commented that such comparison, to our best knowledge, was done in this work for the first time.

\section{Comparison of Different Sample Preparation Procedures}

Suitability of tested sample preparation procedures for both dialyzable and non-dialyzable fractions of elements assessed for coffee brews was evaluated by comparison of sums of mean concentrations of elements and respective pooled standard deviations (SDs, $n=3$ ) determined in these fractions with total concentrations of elements and respective SDs $(n=3)$ determined in these coffee brews. Statistically significant differences between SDs of concentrations of elements were verified using the one-tailed Snedecor-Fisher $F$ test. The critical parameter for this test $\left(F_{\text {critical }}\right)$ at the $95 \%$ significance level $(\alpha=0.05)$ was 19.00 (Konieczka and Namiesnik 2009). Precision of results was additionally expressed as relative standard deviation (\%RSD) of mean concentrations of 
elements and compared between all procedures used. Accuracy of results obtained for compared sample preparation procedures was evaluated by comparison of sums of mean concentrations of elements determined in dialyzable and non-dialyzable fractions separated from coffee brews using particular procedures (P1-P3) to total concentrations of studied elements determined in these coffee brews (a mass balance study). When calculated values of the $F$ test $\left(F_{\text {calulated }}\right)$ were lower than the $F_{\text {critical }}$ value $\left(F_{\text {calulated }}<F_{\text {critical }}\right)$, it meant that SDs of compared results did not differed statistically. In this case, mean concentrations of elements were compared using the Student's $t$ test with the critical value $\left(t_{\text {critical }}\right)$ of 2.776 ( $\alpha=$ 0.05) (Konieczka and Namiesnik 2009). Otherwise, when SDs of compared results differed statistically $\left(F_{\text {calulated }}>\right.$ $\left.F_{\text {critical }}\right)$, the Cochran-Cox $C$ test was used with the critical value $\left(C_{\text {critical }}\right)$ of $4.303(\alpha=0.05)$ (Konieczka and Namiesnik 2009).

Additionally, accuracy of tested sample preparation procedures (P1-P3) of dialyzable and non-dialyzable fractions of coffee brews was estimated by the spike-and-recovery experiment. For this purpose, both mentioned fractions of coffee brews were spiked with a multi-element standard solution at two final concentration levels ( 25 and $50 \mu \mathrm{g} \mathrm{L}^{-1}$ ) and subjected to analysis by ICP OES to assess respective recoveries of added elements. Experiments were carried out in triplicate $(n=3)$ and for all elements except for $\mathrm{Ca}$ and $\mathrm{Mg}$, because concentrations of these elements were much higher than others.

\section{Characteristics of the Analytical Methods}

\section{Precision}

$F_{\text {calculated }}$ values are given in Table 1 . As can be seen, they were generally lower than the critical value $\left(F_{\text {calulated }} F_{\text {critical }}\right)$, what indicated that there were no statistically significant differences between SDs of compared results. Several exceptions were observed however. Accordingly, in case of GC2 it was noted for $\mathrm{Mg}(\mathrm{P} 2)$ and $\mathrm{Ba}(\mathrm{P} 3)$. In case of IC2, the number of exceptions was higher, probably due to a more complex matrix of IC2 as compared to the matrix of $\mathrm{GC} 2$, and included $\mathrm{Ca}$ and $\mathrm{Fe}$ (in case of $\mathrm{P} 1$ and P2), as well as $\mathrm{Ba}, \mathrm{Ni}$, and $\mathrm{Sr}$ (in case of $\mathrm{P} 3$ ).

In terms of RSDs (Table 2), precision of measurements obtained for $\mathrm{GC} 2$ using sample preparation procedures $\mathrm{P} 1$ (0.61-5.5\%) and P2 (0.72-3.1\%) was comparable. In case of the procedure $\mathrm{P} 3$, precision was slightly worse, i.e., 1.0 $8.5 \%$. Similar results were achieved for IC2; ranges of RSD values obtained for studied elements were as follows: 0.30 $5.3 \%, 0.54-5.9 \%$, and $0.79-9.5 \%$ for sample preparation procedures $\mathrm{P} 1, \mathrm{P} 2$, and $\mathrm{P} 3$, respectively.
Table 1 Calculated values of $F$ - $\left(F_{\text {calculated }}\right)$ and $t$ - $\left(t_{\text {calculated }}\right)$ tests for comparison of sums of mean concentrations of elements in dialyzable and non-dialyzable fractions of brews of GC2 and IC2 coffees obtained with different sample preparation procedures, i.e., wet digestion (P1), direct analysis (P2), and acidification with $\mathrm{HNO}_{3}(\mathrm{P} 3)$ with total concentrations of elements determined in these coffee brews, prior to FAAS $(\mathrm{Ca}, \mathrm{Mg})$ and ICP OES (Al, Ba, Cr, $\mathrm{Cu}, \mathrm{Fe}, \mathrm{Mn}, \mathrm{Ni}, \mathrm{Sr}, \mathrm{Zn}$ ) measurements. Significant differences are italicized

\begin{tabular}{|c|c|c|c|c|c|c|c|c|c|c|c|c|}
\hline & \multicolumn{6}{|c|}{ Brews of GC2 } & \multicolumn{6}{|c|}{ Brews of IC2 } \\
\hline & \multicolumn{3}{|c|}{$F_{\text {calculated }}$} & \multicolumn{3}{|c|}{$t_{\text {calculated }}$} & \multicolumn{3}{|c|}{$F_{\text {calculated }}$} & \multicolumn{3}{|c|}{$t_{\text {calculated }}$} \\
\hline & $\mathrm{P} 1$ & $\mathrm{P} 2$ & P3 & $\mathrm{P} 1$ & $\mathrm{P} 2$ & P3 & $\mathrm{P} 1$ & $\mathrm{P} 2$ & P3 & $\mathrm{P} 1$ & $\mathrm{P} 2$ & P3 \\
\hline $\mathrm{Al}$ & 1.35 & 4.62 & 3.46 & 1.996 & 0.584 & 1.418 & 2.25 & 2.25 & 25.00 & 0.961 & 0.000 & $0.277^{\mathrm{a}}$ \\
\hline $\mathrm{Ba}$ & 1.00 & 2.25 & 30.25 & 1.225 & 0.961 & $0.885^{\mathrm{a}}$ & 11.11 & 11.11 & 81.00 & 2.323 & 2.157 & $4.529^{a}$ \\
\hline $\mathrm{Ca}$ & 1.27 & 1.56 & 5.64 & 0.432 & 1.082 & 2.436 & 20.25 & 20.25 & 4.48 & $0.460^{\mathrm{a}}$ & $0.383^{\mathrm{a}}$ & 1.566 \\
\hline $\mathrm{Cr}$ & - & - & - & - & - & - & 1.28 & 18.06 & 3.57 & 0.688 & 0.397 & 3.332 \\
\hline $\mathrm{Cu}$ & 12.25 & 1.56 & 10.56 & 1.071 & 0.541 & 1.146 & 12.25 & 16.00 & 12.25 & 0.714 & 0.210 & 2.141 \\
\hline $\mathrm{Fe}$ & 1.44 & 2.25 & 1.00 & 1.996 & 0.961 & 0.612 & 156.25 & 25.00 & 17.36 & $1.184^{\mathrm{a}}$ & $0.333^{\mathrm{a}}$ & 4.648 \\
\hline $\mathrm{Mg}$ & 4.00 & 16.00 & 16.00 & 2.324 & 1.680 & 17.644 & 2.78 & 2.25 & 3.52 & 2.178 & 0.865 & 3.057 \\
\hline $\mathrm{Mn}$ & 1.00 & 1.00 & 16.00 & 1.225 & 0.612 & 2.941 & 1.00 & 1.00 & 7.11 & 0.816 & 1.225 & 13.380 \\
\hline $\mathrm{Ni}$ & 16.00 & 4.00 & 1.56 & 1.260 & 0.581 & 1.860 & 16.00 & 2.25 & 462.25 & 1.470 & 0.961 & $1.248^{\mathrm{a}}$ \\
\hline $\mathrm{Sr}$ & 1.56 & 2.56 & 17.64 & 2.435 & 1.102 & 4.894 & 9.00 & 9.00 & 169.00 & 2.191 & 1.643 & $1.627^{\mathrm{a}}$ \\
\hline $\mathrm{Zn}$ & 1.44 & 2.25 & 1.78 & 0.222 & 1.201 & 2.944 & 1.09 & 1.09 & 3.47 & 0.707 & 1.197 & 2.643 \\
\hline
\end{tabular}

The critical value of the $F$ test $\left(F_{\text {critical }}\right), 19.00(\alpha=0.05)$

The critical value of the $t$ test $\left(t_{\text {critical }}\right), 2.776(\alpha=0.05)$

${ }^{\text {a }}$ The $C$ test Cochran-Cox was used with the critical value $\left(C_{\text {critical }}\right), 4.303(\alpha=0.05)$ 
Table 2 Total concentrations (in $\mu \mathrm{g} \mathrm{L}^{-1}$ ) of elements determined by FAAS (Ca, Mg) and ICP OES (Al, Ba, $\mathrm{Cr}, \mathrm{Cu}, \mathrm{Fe}, \mathrm{Mn}, \mathrm{Ni}, \mathrm{Sr}, \mathrm{Zn})$ in brews of ground (GC2) and instant (IC2) coffees and concentrations of elements in dialyzable and non-dialyzable fractions after application of different sample preparation procedures, i.e., wet digestion (P1), direct analysis (P2), and acidification with $\mathrm{HNO}_{3}(\mathrm{P} 3)$
Brew of GC2

\section{P1}

P1

Al

$C_{\mathrm{t}}$

A: dialyzate

$B$ : non-dialyzate

Sum $(A \text { and } B)^{\mathrm{a}}$

Agreement $^{\mathrm{b}}$

$\mathrm{Ba}$

$C_{\mathrm{t}}$

A: dialyzate

$B$ : non-dialyzate

Sum $(A \text { and } B)^{\text {a }}$

Agreement $^{\mathrm{b}}$

$\mathrm{Ca} / 10^{3}$

$C_{\mathrm{t}}$

$A$ : dialyzate

$B$ : non-dialyzate

Sum $(A \text { and } B)^{\mathrm{a}}$

Agreement ${ }^{\mathrm{b}}$

$\mathrm{Cr}$

$\mathrm{C}_{\mathrm{t}}$

$A$ : dialyzate

$B$ : non-dialyzate

Sum $(A \text { and } B)^{\mathrm{a}}$

Agreement $^{\mathrm{b}}$

$\mathrm{Cu}$

$C_{\mathrm{t}}$

$A$ : dialyzate

$B$ : non-dialyzate

Sum $(A \text { and } B)^{\mathrm{a}}$

Agreement $^{\mathrm{b}}$

$\mathrm{Fe}$

$C_{\mathrm{t}}$

$A$ : dialyzate

$B$ : non-dialyzate

Sum $(A \text { and } B)^{\mathrm{a}}$

Agreement ${ }^{\mathrm{b}}$

$\mathrm{Mg} / 10^{3}$

$C_{\mathrm{t}}$

A: dialyzate

$B$ : non-dialyzate

Sum $(A \text { and } B)^{\mathrm{a}}$

Agreement $^{\mathrm{b}}$

$\mathrm{Mn}$

$C_{\mathrm{t}}$

A: dialyzate
$1.90 \pm 0.09$

$8.77 \pm 0.48$

$10.7 \pm 0.5$

$108 \pm 5$

$17.1 \pm 0.2$

$6.79 \pm 0.20$

$10.1 \pm 0.1$

$16.9 \pm 0.2$

$98.8 \pm 1.2$

$32.4 \pm 0.8$

$12.9 \pm 0.6$

$19.8 \pm 0.4$

$32.7 \pm 0.9$

$101 \pm 3$

$2.76 \pm 0.24$

$<0.17^{\mathrm{b}}$

$<0.44^{\mathrm{b}}$

$-$$$
-
$$

$24.7 \pm 0.4$

$21.9 \pm 1.2$

$25.6 \pm 1.4$

$104 \pm 6$

$129 \pm 6$

$7.91 \pm 0.37$

$120 \pm 5$

$128 \pm 5$

$99.2 \pm 4.0$

$42.2 \pm 0.1$

$15.4 \pm 0.1$

$26.5 \pm 0.1$

$41.9 \pm 0.2$

$99.3 \pm 0.6$

$216 \pm 2$

$61.5 \pm 0.7$
$3.68 \pm 0.16$
P2

2

P3

$9.94+0.43$

$1.49 \pm 0.06$

$8.58 \pm 0.31$

$10.1 \pm 0.2$

$102 \pm 3$

$17.1 \pm 0.2$

$6.97 \pm 0.17$

$9.92 \pm 0.22$

$16.9 \pm 0.3$

$98.8 \pm 1.8$

$32.4 \pm 0.8$

$13.2 \pm 0.5$

$20.0 \pm 0.6$

$33.2 \pm 1.0$

$102 \pm 3$

$2.76 \pm 0.24$

$<0.14^{\mathrm{b}}$

$<0.33^{\mathrm{b}}$

$-$

$24.7 \pm 0.4$

$3.33 \pm 0.11$

$21.6 \pm 0.4$

$24.9 \pm 0.5$

$101 \pm 2$

$129 \pm 6$

$6.90 \pm 0.24$

$125 \pm 4$

$132 \pm 4$

$102 \pm 3$

$42.2 \pm 0.1$

$16.0 \pm 0.2$

$26.6 \pm 0.3$

$42.6 \pm 0.4$

$101 \pm 1$

$216 \pm 2$

$60.0 \pm 1.3$
$9.94 \pm 0.43$
$2.01 \pm 0.15$
$7.39 \pm 0.66$
$9.40 \pm 0.80$
$94.6 \pm 8.0$

$17.1 \pm 0.2$

$5.23 \pm 0.52$

$11.2 \pm 0.6$

$16.4 \pm 1.1$

$95.9 \pm 6.1$

$32.4 \pm 0.8$

$15.8 \pm 1.1$

$19.5 \pm 0.9$

$35.3 \pm 1.9$

$109 \pm 6$

$2.76 \pm 0.24$

$<0.35^{\mathrm{b}}$

$<0.46^{\mathrm{b}}$

$-$

-

$24.7 \pm 0.4$

$3.89 \pm 0.16$

$19.9 \pm 1.4$

$23.8 \pm 1.3$

$96.4 \pm 5.2$

$129 \pm 6$

$5.40 \pm 0.26$

$132 \pm 5$

$137 \pm 6$

$106 \pm 5$

$42.2 \pm 0.1$

$16.1 \pm 0.7$

$21.9 \pm 0.4$

$38.0 \pm 0.4$

$90.0 \pm 0.9$

$216 \pm 2$

$63.3 \pm 3.8$
Brew of IC2

\begin{tabular}{lll}
\hline $\mathrm{P} 1$ & $\mathrm{P} 2$ & $\mathrm{P} 3$
\end{tabular}

P3

$\begin{array}{lll}116 \pm 2 & 116 \pm 2 & 116 \pm 2 \\ 25.6 \pm 0.1 & 22.9 \pm 0.1 & 18.4 \pm 2.8 \\ 92.0 \pm 3.1 & 92.6 \pm 2.8 & 100 \pm 4 \\ 118 \pm 3 & 116 \pm 3 & 118 \pm 10 \\ 102 \pm 3 & 100 \pm 3 & 102 \pm 5\end{array}$

$59.4 \pm 0.3$

$59.4 \pm 0.3$

$59.4 \pm 0.3$

$28.3 \pm 0.3$

$32.5 \pm 0.8$

$60.8 \pm 1.0$

$102 \pm 2$

$63.7 \pm 3.6$

$27.8 \pm 1.1$

$37.1 \pm 0.5$

$64.9 \pm 0.8$

$102 \pm 1$

$3.07 \pm 0.17$

$1.01 \pm 0.03$

$2.15 \pm 0.12$

$3.16 \pm 0.15$

$103 \pm 5$

$28.5 \pm 0.8$

$32.2 \pm 0.4$

$60.7 \pm 1.0$

$102 \pm 2$

$32.9 \pm 3.3$

$35.2 \pm 1.8$

$68.1 \pm 2.7$

$115 \pm 4$

$63.7 \pm 3.6$

$63.7 \pm 3.6$

$26.2 \pm 0.1$

$38.5 \pm 0.9$

$64.7 \pm 0.8$

$102 \pm 1$

$23.4 \pm 0.9$

$43.9 \pm 0.7$

$67.3 \pm 1.7$

$106 \pm 3$

$3.07 \pm 0.17$

$3.07 \pm 0.17$

$0.970 \pm 0.026$

$<0.35^{\mathrm{b}}$

$2.06 \pm 0.07$

$2.35 \pm 0.06$

$3.03 \pm 0.04$

$2.70 \pm 0.09$

$88.0 \pm 2.8$

$12.9 \pm 0.2$

$1.10 \pm 0.02$

$12.1 \pm 0.7$

$13.2 \pm 0.7$

$102 \pm 6$

$849 \pm 25$

$13.4 \pm 0.5$

$815 \pm 2$

$828 \pm 2$

$97.5 \pm 0.3$

$12.9 \pm 0.2$

$12.9 \pm 0.2$

$1.35 \pm 0.02$

$1.42 \pm 0.09$

$11.6 \pm 0.8$

$12.4 \pm 0.7$

$13.0 \pm 0.8$

$13.8 \pm 0.7$

$107 \pm 5$

$101 \pm 6$

$849 \pm 25$

$849 \pm 25$

$14.4 \pm 0.6$

$829 \pm 4$

$843 \pm 5$

$99.3 \pm 0.5$

$55.8 \pm 3.7$

$734 \pm 4$

$780 \pm 6$

$91.9 \pm 0.7$

$70.4 \pm 1.5$

$70.4 \pm 1.5$

$70.4 \pm 1.5$

$30.9 \pm 0.6$

$41.7 \pm 0.4$

$28.7 \pm 0.4$

$23.4 \pm 0.7$

$40.8 \pm 0.6$

$44.0 \pm 1.4$

$72.6 \pm 0.9$

$69.5 \pm 1.0$

$67.4 \pm 0.8$

$103 \pm 1$

$98.7 \pm 1.4$

$95.7 \pm 1.1$

$325 \pm 3$

$104 \pm 4$
$325 \pm 3$

$99.8 \pm 1.0$
$325 \pm 3$

$118 \pm 3$ 
Table 2 (continued)

\begin{tabular}{|c|c|c|c|c|c|c|}
\hline & \multicolumn{3}{|c|}{ Brew of GC2 } & \multicolumn{3}{|c|}{ Brew of IC2 } \\
\hline & $\mathrm{P} 1$ & $\mathrm{P} 2$ & P3 & $\mathrm{P} 1$ & $\mathrm{P} 2$ & P3 \\
\hline$B$ : non-dialyzate & $156 \pm 1$ & $155 \pm 2$ & $167 \pm 7$ & $223 \pm 7$ & $222 \pm 2$ & $273 \pm 5$ \\
\hline $\operatorname{Sum}(A \text { and } B)^{\mathrm{a}}$ & $218 \pm 2$ & $215 \pm 2$ & $230 \pm 8$ & $327 \pm 3$ & $322 \pm 3$ & $391 \pm 8$ \\
\hline Agreement $^{\mathrm{b}}$ & $101 \pm 1$ & $99.5 \pm 0.7$ & $106 \pm 4$ & $101 \pm 1$ & $99.1 \pm 0.8$ & $120 \pm 2$ \\
\hline \multicolumn{7}{|l|}{$\mathrm{Ni}$} \\
\hline$C_{\mathrm{t}}$ & $24.1 \pm 0.8$ & $24.1 \pm 0.8$ & $24.1 \pm 0.8$ & $41.6 \pm 0.2$ & $41.6 \pm 0.2$ & $41.6 \pm 0.2$ \\
\hline$A$ : dialyzate & $10.8 \pm 0.3$ & $9.77 \pm 0.17$ & $8.99 \pm 0.40$ & $24.3 \pm 0.4$ & $25.1 \pm 0.3$ & $19.9 \pm 1.0$ \\
\hline$B$ : non-dialyzate & $13.9 \pm 0.4$ & $14.0 \pm 0.3$ & $17.2 \pm 0.6$ & $16.6 \pm 0.4$ & $16.3 \pm 0.4$ & $25.5 \pm 3.3$ \\
\hline $\operatorname{Sum}(A \text { and } B)^{\mathrm{a}}$ & $24.7 \pm 0.2$ & $23.8 \pm 0.4$ & $26.2 \pm 1.0$ & $40.9 \pm 0.8$ & $41.4 \pm 0.3$ & $45.4 \pm 4.3$ \\
\hline Agreement ${ }^{\mathrm{b}}$ & $102 \pm 1$ & $98.8 \pm 1.7$ & $109 \pm 4$ & $98.3 \pm 2$ & $99.5 \pm 0.6$ & $109 \pm 6$ \\
\hline \multicolumn{7}{|l|}{$\mathrm{Sr}$} \\
\hline$C_{\mathrm{t}}$ & $57.3 \pm 0.5$ & $57.3 \pm 0.5$ & $57.3 \pm 0.5$ & $142 \pm 1$ & $142 \pm 1$ & $142 \pm 1$ \\
\hline A: dialyzate & $23.4 \pm 0.5$ & $24.6 \pm 0.3$ & $27.6 \pm 0.8$ & $63.2 \pm 0.3$ & $66.2 \pm 1.9$ & $72.7 \pm 2.8$ \\
\hline$B$ : non-dialyzate & $34.8 \pm 0.9$ & $33.3 \pm 0.7$ & $35.8 \pm 1.6$ & $82.8 \pm 1.8$ & $78.9 \pm 1.6$ & $84.7 \pm 10.2$ \\
\hline $\operatorname{Sum}(A \text { and } B)^{\mathrm{a}}$ & $58.2 \pm 0.4$ & $57.9 \pm 0.8$ & $63.4 \pm 2.1$ & $146 \pm 3$ & $145 \pm 3$ & $157 \pm 13$ \\
\hline Agreement ${ }^{\mathrm{b}}$ & $102 \pm 1$ & $101 \pm 1$ & $111 \pm 5$ & $103 \pm 2$ & $102 \pm 2$ & $111 \pm 7$ \\
\hline \multicolumn{7}{|l|}{$\mathrm{Zn}$} \\
\hline$C_{\mathrm{t}}$ & $21.2 \pm 0.6$ & $21.2 \pm 0.6$ & $21.2 \pm 0.6$ & $89.4 \pm 2.2$ & $89.4 \pm 2.2$ & $89.4 \pm 2.2$ \\
\hline A: dialyzate & $2.14 \pm 0.08$ & $2.30 \pm 0.05$ & $2.59 \pm 0.06$ & $11.2 \pm 0.4$ & $9.37 \pm 0.33$ & $11.2 \pm 0.4$ \\
\hline$B$ : non-dialyzate & $19.0 \pm 0.5$ & $19.4 \pm 0.4$ & $20.3 \pm 0.8$ & $79.5 \pm 2.2$ & $82.2 \pm 2.0$ & $85.3 \pm 4.2$ \\
\hline $\operatorname{Sum}(A \text { and } B)^{\mathrm{a}}$ & $21.1 \pm 0.5$ & $21.7 \pm 0.4$ & $22.9 \pm 0.8$ & $90.7 \pm 2.3$ & $91.6 \pm 2.3$ & $96.5 \pm 4.1$ \\
\hline Agreement ${ }^{\mathrm{b}}$ & $99.5 \pm 2.6$ & $102 \pm 2$ & $108 \pm 4$ & $101 \pm 3$ & $102 \pm 2$ & $108 \pm 4.8$ \\
\hline
\end{tabular}

Mean values $(n=3)$ with standard deviations (SDs)

${ }^{a}$ Agreement was calculated as $(\%)=100 \times(\operatorname{Sum}(A$ and $B)) / \mathrm{C}_{\mathrm{t}}$

${ }^{\mathrm{b}}$ Below the limit of detection (LOD) $\left(\mu \mathrm{g} \mathrm{L}{ }^{-1}\right)$

\section{Accuracy}

Total concentrations of elements determined by F AAS and ICP OES in brews of GC2 and IC2 as well as concentrations of elements in dialyzable and non-dialyzable fractions prepared using sample preparation procedures P1-P3 are given in Table 2. Values of the $t$ and $C$ tests are presented in Table 1. These tests were employed to verify significance of differences between sums of mean concentrations of elements in dialyzable and non-dialyzable fractions separated from coffee brews and their total concentrations in these brews. Accordingly, it was established that sums of mean concentrations of elements determined in dialyzable and non-dialyzable fractions of coffee brews after their prior wet digestion (P1) and direct analysis (P2) did not statistically differ from total concentrations of these elements determined in these brews. In this case, for all studied elements, $t_{\text {calculated }}$ or $C_{\text {calculated }}$ values were lower than respective critical values of both tests, i.e., $t_{\text {critical }}=2.776$ and $C_{\text {critical }}=4.303$. The lack of differences between compared values suggests that wet digestion (P1) and direct analysis (P2) of dialyzable and non-dialyzable fractions of coffee brews provide comparable results. However, compared to the sample preparation procedure $\mathrm{P} 1$, the second procedure (P2) was much faster and easier. Considering the procedure $\mathrm{P} 3$ (acidification with $\mathrm{HNO}_{3}$ ), statistically significant differences between results were established for $\mathrm{Mg}, \mathrm{Mn}$, $\mathrm{Sr}$, and $\mathrm{Zn}$ (in case of GC2) and for $\mathrm{Ba}, \mathrm{Cr}, \mathrm{Fe}, \mathrm{Mg}$, and $\mathrm{Mn}$ (in case of IC2). The latter sample preparation procedure could alternatively be used instead of total sample decomposition of dialyzates and residues of samples by wet digestion (P1) or direct analysis (P2) only in case of few selected elements, i.e., $\mathrm{Al}, \mathrm{Ca}, \mathrm{Cu}$, and $\mathrm{Ni}$.

Additionally, it was established (see Table 3) that, independently of the spike level, wet digestion (P1) and direct analysis (P2) as sample preparation procedures of dialyzates and residues of samples shown the most adequate accuracy and provided quantitative recoveries for all elements. Respective recovery values obtained for all studied elements in brews of GC2 and IC2 were as follows: GC2 [P1 (98.4-104\% and 99.7-104\%), P2 (98.4-104\% and 98.1-104\%)] and IC2 [P1 (98.7-103\% and 98.7-105\%), P2 (98.2-102\% and 98.0-104\%)] for dialyzable and non-dialyzable fractions, respectively. In case of acidification with $\mathrm{HNO}_{3}$ (P3), the following recoveries were obtained: GC2 
Table 3 Recoveries of elements from dialyzable and nondialyzable fractions of brews of ground (GC2) and instant (IC2) coffees prepared before analysis using different sample preparation procedures, i.e., wet digestion $(\mathrm{P} 1)$, direct analysis $(\mathrm{P} 2)$, and acidification with $\mathrm{HNO}_{3}(\mathrm{P} 3)$

\begin{tabular}{|c|c|c|c|c|c|c|c|}
\hline & \multirow[t]{3}{*}{ Addition $\left(\mu \mathrm{g} \mathrm{L}^{-1}\right)$} & \multicolumn{6}{|c|}{ Recovery, \% } \\
\hline & & \multicolumn{3}{|c|}{ Dialyzable fraction } & \multicolumn{3}{|c|}{ Non-dialyzable fraction } \\
\hline & & $\mathrm{P} 1$ & $\mathrm{P} 2$ & P3 & $\mathrm{P} 1$ & $\mathrm{P} 2$ & P3 \\
\hline \multicolumn{8}{|c|}{ Brews of GC2 } \\
\hline \multirow[t]{2}{*}{$\mathrm{Al}$} & 25 & $102 \pm 1$ & $102 \pm 2$ & $106 \pm 1$ & $99.9 \pm 1.0$ & $99.3 \pm 0.3$ & $94.4 \pm 0.5$ \\
\hline & 50 & $104 \pm 1$ & $104 \pm 1$ & $104 \pm 1$ & $104 \pm 1$ & $101 \pm 1$ & $97.2 \pm 1.3$ \\
\hline \multirow[t]{2}{*}{$\mathrm{Ba}$} & 25 & $102 \pm 1$ & $100 \pm 1$ & $93.2 \pm 1.9$ & $101 \pm 2$ & $100 \pm 1$ & $118 \pm 4$ \\
\hline & 50 & $102 \pm 1$ & $98.8 \pm 0.3$ & $95.0 \pm 1.7$ & $103 \pm 1$ & $98.1 \pm 0.5$ & $110 \pm 4$ \\
\hline \multirow[t]{2}{*}{$\mathrm{Cr}$} & 25 & $104 \pm 1$ & $100 \pm 1$ & $102 \pm 2$ & $102 \pm 2$ & $101 \pm 1$ & $105 \pm 1$ \\
\hline & 50 & $103 \pm 1$ & $100 \pm 1$ & $102 \pm 1$ & $104 \pm 2$ & $103 \pm 1$ & $105 \pm 1$ \\
\hline \multirow[t]{2}{*}{$\mathrm{Cu}$} & 25 & $100 \pm 1$ & $101 \pm 2$ & $106 \pm 1$ & $101 \pm 2$ & $100 \pm 1$ & $93.6 \pm 1.3$ \\
\hline & 50 & $101 \pm 1$ & $99.3 \pm 0.3$ & $105 \pm 2$ & $103 \pm 1$ & $98.9 \pm 0.1$ & $96.8 \pm 1.2$ \\
\hline \multirow[t]{2}{*}{$\mathrm{Fe}$} & 25 & $99.2 \pm 3.3$ & $98.7 \pm 1.3$ & $92.4 \pm 1.3$ & $102 \pm 2$ & $104 \pm 1$ & $108 \pm 1$ \\
\hline & 50 & $98.9 \pm 0.5$ & $98.4 \pm 1.5$ & $97.2 \pm 1.4$ & $104 \pm 1$ & $102 \pm 1$ & $108 \pm 1$ \\
\hline \multirow[t]{2}{*}{$\mathrm{Mn}$} & 25 & $102 \pm 1$ & $98.5 \pm 1.2$ & $106 \pm 1$ & $104 \pm 1$ & $101 \pm 1$ & $106 \pm 1$ \\
\hline & 50 & $103 \pm 1$ & $100 \pm 0.2$ & $104 \pm 1$ & $103 \pm 1$ & $98.6 \pm 0.5$ & $104 \pm 1$ \\
\hline \multirow[t]{2}{*}{$\mathrm{Ni}$} & 25 & $102 \pm 1$ & $102 \pm 2$ & $106 \pm 1$ & $101 \pm 2$ & $102 \pm 2$ & $105 \pm 3$ \\
\hline & 50 & $102 \pm 1$ & $101 \pm 1$ & $106 \pm 1$ & $103 \pm 1$ & $102 \pm 1$ & $105 \pm 1$ \\
\hline \multirow[t]{2}{*}{$\mathrm{Sr}$} & 25 & $104 \pm 1$ & $103 \pm 1$ & $108 \pm 2$ & $99.7 \pm 1.4$ & $101 \pm 1$ & $122 \pm 3$ \\
\hline & 50 & $103 \pm 1$ & $103 \pm 1$ & $111 \pm 6$ & $102 \pm 2$ & $100 \pm 1$ & $112 \pm 5$ \\
\hline \multirow[t]{2}{*}{$\mathrm{Zn}$} & 25 & $98.4 \pm 0.3$ & $98.8 \pm 1.2$ & $106 \pm 1$ & $103 \pm 2$ & $102 \pm 1$ & $90.6 \pm 4.0$ \\
\hline & 50 & $100 \pm 1$ & $99.3 \pm 0.4$ & $106 \pm 2$ & $104 \pm 1$ & $102 \pm 1$ & $93.0 \pm 0.9$ \\
\hline \multicolumn{8}{|c|}{ Brews of IC2 } \\
\hline \multirow[t]{2}{*}{$\mathrm{Al}$} & 25 & $101 \pm 1$ & $100 \pm 2$ & $106 \pm 2$ & $105 \pm 1$ & $101 \pm 1$ & $96.2 \pm 2.1$ \\
\hline & 50 & $102 \pm 1$ & $102 \pm 1$ & $102 \pm 1$ & $103 \pm 1$ & $99.5 \pm 1.2$ & $96.0 \pm 0.4$ \\
\hline \multirow[t]{2}{*}{$\mathrm{Ba}$} & 25 & $102 \pm 1$ & $98.8 \pm 0.8$ & $109 \pm 3$ & $102 \pm 1$ & $101 \pm 1$ & $117 \pm 1$ \\
\hline & 50 & $101 \pm 1$ & $99.0 \pm 0.1$ & $107 \pm 3$ & $104 \pm 1$ & $98.4 \pm 0.6$ & $107 \pm 1$ \\
\hline \multirow[t]{2}{*}{$\mathrm{Cr}$} & 25 & $102 \pm 1$ & $99.8 \pm 0.8$ & $101 \pm 1$ & $105 \pm 1$ & $104 \pm 2$ & $108 \pm 1$ \\
\hline & 50 & $102 \pm 1$ & $100 \pm 1$ & $101 \pm 1$ & $105 \pm 1$ & $101 \pm 1$ & $106 \pm 2$ \\
\hline \multirow[t]{2}{*}{$\mathrm{Cu}$} & 25 & $99.4 \pm 0.7$ & $98.7 \pm 0.7$ & $114 \pm 5$ & $103 \pm 1$ & $98.4 \pm 1.6$ & $116 \pm 2$ \\
\hline & 50 & $102 \pm 1$ & $101 \pm 1$ & $107 \pm 1$ & $104 \pm 1$ & $100 \pm 1$ & $108 \pm 1$ \\
\hline \multirow[t]{2}{*}{$\mathrm{Fe}$} & 25 & $103 \pm 1$ & $100 \pm 1$ & $88.6 \pm 1.1$ & $98.7 \pm 0.6$ & $99.7 \pm 1.6$ & $108 \pm 1$ \\
\hline & 50 & $102 \pm 1$ & $99.2 \pm 1.2$ & $95.1 \pm 1.4$ & $101 \pm 1$ & $99.4 \pm 0.4$ & $104 \pm 1$ \\
\hline \multirow[t]{2}{*}{$\mathrm{Mn}$} & 25 & $101 \pm 1$ & $99.9 \pm 0.3$ & $101 \pm 1$ & $100 \pm 1$ & $102 \pm 1$ & $107 \pm 1$ \\
\hline & 50 & $102 \pm 1$ & $98.2 \pm 0.7$ & $103 \pm 2$ & $102 \pm 1$ & $98.6 \pm 1.0$ & $107 \pm 1$ \\
\hline \multirow[t]{2}{*}{$\mathrm{Ni}$} & 25 & $102 \pm 1$ & $99.1 \pm 0.2$ & $104 \pm 2$ & $102 \pm 1$ & $100 \pm 1$ & $105 \pm 1$ \\
\hline & 50 & $102 \pm 1$ & $98.5 \pm 0.8$ & $104 \pm 1$ & $104 \pm 1$ & $99.9 \pm 0.4$ & $105 \pm 1$ \\
\hline \multirow[t]{2}{*}{$\mathrm{Sr}$} & 25 & $103 \pm 1$ & $99.4 \pm 0.8$ & $108 \pm 4$ & $98.8 \pm 0.4$ & $98.8 \pm 1.8$ & $113 \pm 3$ \\
\hline & 50 & $102 \pm 1$ & $102 \pm 1$ & $106 \pm 2$ & $103 \pm 1$ & $98.0 \pm 1.3$ & $107 \pm 2$ \\
\hline \multirow[t]{2}{*}{$\mathrm{Zn}$} & 25 & $98.7 \pm 0.5$ & $98.4 \pm 0.2$ & $112 \pm 4$ & $99.0 \pm 0.4$ & $102 \pm 1$ & $95.3 \pm 2.8$ \\
\hline & 50 & $99.9 \pm 0.6$ & $100 \pm 1$ & $106 \pm 1$ & $102 \pm 1$ & $100 \pm 1$ & $95.8 \pm 0.1$ \\
\hline
\end{tabular}

Mean values $(n=3) \pm$ standard deviation
(92.4-111\% and 90.6-122\%) and IC2 (88.6-114\% and 95.3-117\%) for dialyzable and non-dialyzable fractions, respectively, indicating that this procedure was unsuitable to prepare sample solutions after in vitro gastrointestinal digestion before their subsequent ICP OES measurements.

\section{Limits of Detection and Limits of Quantification}

Limits of detection (LODs) and limits of quantification (LOQs) of elements achieved with ICP OES and different sample preparation procedures were calculated (in $\mu \mathrm{g} \mathrm{L}^{-1}$ ) using a $3 \sigma$ criterion and $10 \sigma$ criterion, respectively. Because 
Table 4 Limits of detection (LODs) and limits of quantification (LOQs) of elements assessed for ICP OES (Al, Ba, Cr, Cu, Fe, Mn, Ni, Sr, $\mathrm{Zn}$ ) combined with different sample preparation procedures (dialyzable and non-dialyzable fractions), i.e., wet digestion ( $\mathrm{P} 1)$, direct analysis (P2), and acidification with $\mathrm{HNO}_{3}(\mathrm{P} 3)$

\begin{tabular}{|c|c|c|c|c|c|c|}
\hline & \multicolumn{6}{|c|}{$\mathrm{LOD}(\mathrm{LOQ})\left(\mu \mathrm{g} \mathrm{L}^{-1}\right)$} \\
\hline & \multicolumn{3}{|c|}{ Dialyzable fraction } & \multicolumn{3}{|c|}{ Non-dialyzable fraction } \\
\hline & $\mathrm{P} 1$ & $\mathrm{P} 2$ & $\mathrm{P} 3$ & $\mathrm{P} 1$ & $\mathrm{P} 2$ & P3 \\
\hline $\mathrm{Al}$ & $0.45(1.5)$ & $0.34(1.1)$ & $0.60(2.0)$ & $1.3(4.3)$ & $1.1(3.7)$ & $1.6(5.3)$ \\
\hline $\mathrm{Ba}$ & $0.077(0.26)$ & $0.095(0.32)$ & $1.0(3.3)$ & $0.14(0.47)$ & $0.17(0.57)$ & $0.61(2.0)$ \\
\hline $\mathrm{Cr}$ & $0.17(0.57)$ & $0.14(0.47)$ & $0.35(1.2)$ & $0.44(1.5)$ & $0.33(1.1)$ & $0.46(1.5)$ \\
\hline $\mathrm{Cu}$ & $0.26(0.87)$ & $0.37(1.2)$ & $0.39(1.3)$ & $1.3(4.3)$ & $0.53(1.8)$ & $1.9(6.3)$ \\
\hline $\mathrm{Fe}$ & $1.3(4.3)$ & $0.81(2.7)$ & $2.0(6.7)$ & $2.6(8.7)$ & $1.5(5.0)$ & $2.5(8.3)$ \\
\hline $\mathrm{Mn}$ & $0.12(0.40)$ & $0.13(0.43)$ & $2.4(8.0)$ & $0.33(1.1)$ & $0.25(0.83)$ & $2.1(7.0)$ \\
\hline $\mathrm{Ni}$ & $1.9(6.3)$ & $1.8(6.0)$ & $2.4(8.0)$ & $1.2(4.0)$ & $0.61(2.0)$ & $3.3(11)$ \\
\hline $\mathrm{Sr}$ & $0.087(0.29)$ & $0.23(0.77)$ & $2.1(7.0)$ & $0.32(1.1)$ & $0.36(1.2)$ & $3.8(13)$ \\
\hline $\mathrm{Zn}$ & $0.61(2.0)$ & $0.57(1.9)$ & $0.74(2.5)$ & $1.8(6.0)$ & $1.4(4.7)$ & $2.0(6.7)$ \\
\hline
\end{tabular}

concentrations of $\mathrm{Ca}$ and $\mathrm{Mg}$ were determined against simple aqueous standard solutions, their LODs and LOQs were the same for dialyzable and non-dialyzable fractions and equal to $0.22(\mathrm{Ca})$ and $3.3(\mathrm{Mg}) \mu \mathrm{g} \mathrm{L}^{-1}$ (case of LODs) and $0.73(\mathrm{Ca})$ and $11(\mathrm{Mg}) \mu \mathrm{g} \mathrm{L}^{-1}$ (case of LOQs), for all sample preparation procedures used. As can be seen from Table 4, detectability and quantification of elements attained using wet digestion (P1) and direct analysis (P2) is better than this achieved using acidification with $\mathrm{HNO}_{3}$ (P3). Both, sample preparation procedures P1 and P2 showed comparable values of LODs and LOQs for most elements, except for Fe (in the dialyzable fraction) and $\mathrm{Cu}, \mathrm{Fe}$, and $\mathrm{Ni}$ (in the non-dialyzable fraction), for which better LODs and LOQs were obtained with direct analysis (P2). LODs and LOQs established for $\mathrm{Al}, \mathrm{Cu}, \mathrm{Ni}$, and $\mathrm{Zn}$ (in the dialyzable fraction) and $\mathrm{Al}, \mathrm{Cr}, \mathrm{Fe}$, and $\mathrm{Zn}$ (in the non-dialyzable fraction) when the sample preparation procedure P3 was used were comparable to those obtained for procedures $\mathrm{P} 1$ and $\mathrm{P} 2$. In case of $\mathrm{Ba}, \mathrm{Cr}, \mathrm{Fe}, \mathrm{Mn}$, and $\mathrm{Sr}$ (the dialyzable fraction) and $\mathrm{Ba}, \mathrm{Cu}, \mathrm{Mn}, \mathrm{Ni}$, and $\mathrm{Sr}$ (the nondialyzable fraction), an increase in LOD and LOQ values of these elements by 1 order of magnitude was observed when the procedure P3 was used.

Considering the analytical performance of tested procedures (referring to precision and accuracy of results, LODs and LOQs of elements) as well as their practical point of view (related to time, costs, and simplicity), direct analysis (P2) of dialyzable and non-dialyzable fractions of brews of GCs and ICs guaranteed the most satisfactory and reliable results of their multi-elemental analysis by F AAS and ICP OES.

\section{In Vitro Gastrointestinal Digestion of Ground and Instant Coffee Brews}

The developed and validated methodology was applied to analysis of brews of all GCs and ICs that were subjected to in vitro gastrointestinal digestion. Concentrations of elements in the separated dialyzable fraction of coffee brews are presented in Table 5. Accuracy of the in vitro digestion procedure was established by a mass balance study. For each element, the sum of its concentration in dialyzable and non-dialyzable fractions was compared with its total concentration determined in brews of GCs and ICs. The letter was expressed as recovery $(\%)$ and related to the ratio of the sum of concentration of each element in both fractions to the total concentration in brews of analyzed coffees (see Table 5). As can be seen, recoveries for brews of GCs were quantitative, i.e., 98.4$102 \%$ (Al), 97.4-102\% (Ba), 101-108\% (Ca), 100-105\% $(\mathrm{Cu}), 98.6-104 \%(\mathrm{Fe}), 96.3-101 \%(\mathrm{Mg}), 97.4-101 \%(\mathrm{Mn})$, 98.8-103\% (Ni), 97.8-104\% (Sr), and 99.3-105\% ( $\mathrm{Zn})$. Similar recoveries were also achieved for brews of ICs, i.e., 96.7-100\% (Al), 97.4-103\% (Ba), 95.9-104\% (Ca), 97.2$106 \%(\mathrm{Cr}), 98.5-105 \%(\mathrm{Cu}), 97.3-102 \%(\mathrm{Fe}), 94.2-104 \%$ (Mg), 94.3-99.2\% (Mn), 97.5-102\% (Ni), 97.3-102\% (Sr), and $100.0-105 \%(\mathrm{Zn})$. Considering RSD values assessed for sums of concentrations of elements in dialyzable and nondialyzable fractions of GCs brews, precision of measurements was acceptably good and changed in the following ranges: $0.30-4.8 \%$ (Al), 0.20-1.8\% (Ba), 0.10-3.1\% (Ca), 0.10$3.1 \%(\mathrm{Cu}), 0.30-2.7 \%(\mathrm{Fe}), 0.30-1.4 \%(\mathrm{Mg}), 0.20-1.1 \%$ (Mn), $1.7-2.6 \%(\mathrm{Ni}), 0.10-1.4 \%(\mathrm{Sr})$, and $1.2-4.1 \%(\mathrm{Zn})$. For brews of all ICs, precision was also good because RSDs ranged $0.21-4.7 \%(\mathrm{Al}), 0.29-1.6 \%(\mathrm{Ba}), 0.10-1.4 \%(\mathrm{Ca})$, $0.61-5.4 \%(\mathrm{Cr}), 0.39-6.0 \%(\mathrm{Cu}), 0.10-1.0 \%(\mathrm{Fe}), 0.10$ $1.4 \%(\mathrm{Mg}), 0.10-1.0 \%(\mathrm{Mn}), 0.41-2.4 \%$ (Ni), $0.10-2.0 \%$ (Sr), and $0.10-2.7 \%(\mathrm{Zn})$.

Summarizing, recoveries calculated on the basis of the mass balance study for brews of both groups of coffees were quantitative, i.e., from 95.4 to $108.4 \%$. Precision of measurements was also good and varied on average from 0.10 to $4.8 \%$. Only in two cases, i.e., for $\mathrm{Cr}$ (IC9) and for $\mathrm{Cu}$ (IC2), RSDs were slightly higher, i.e., $5.4 \%$ and $6.0 \%$, respectively. 


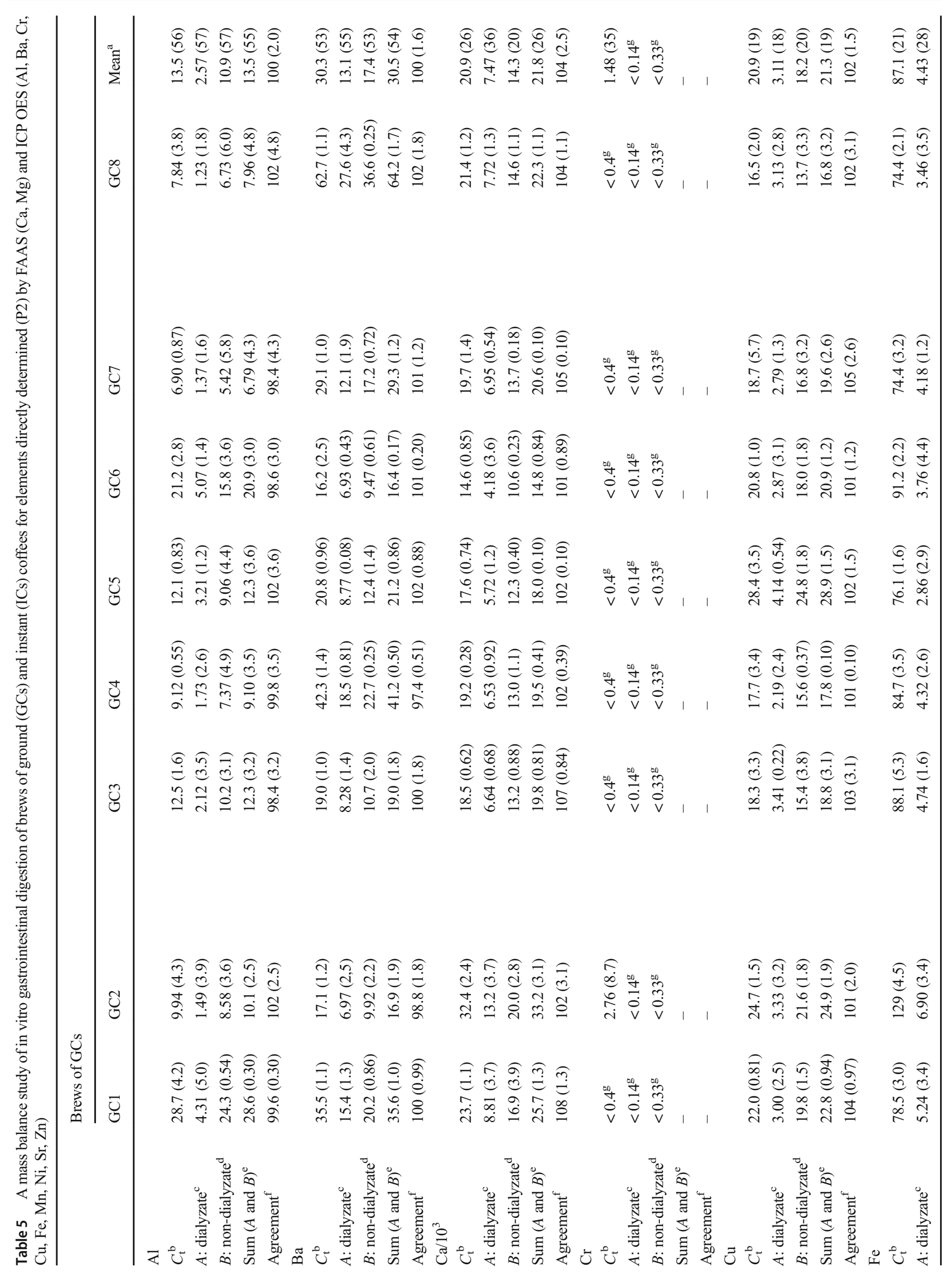




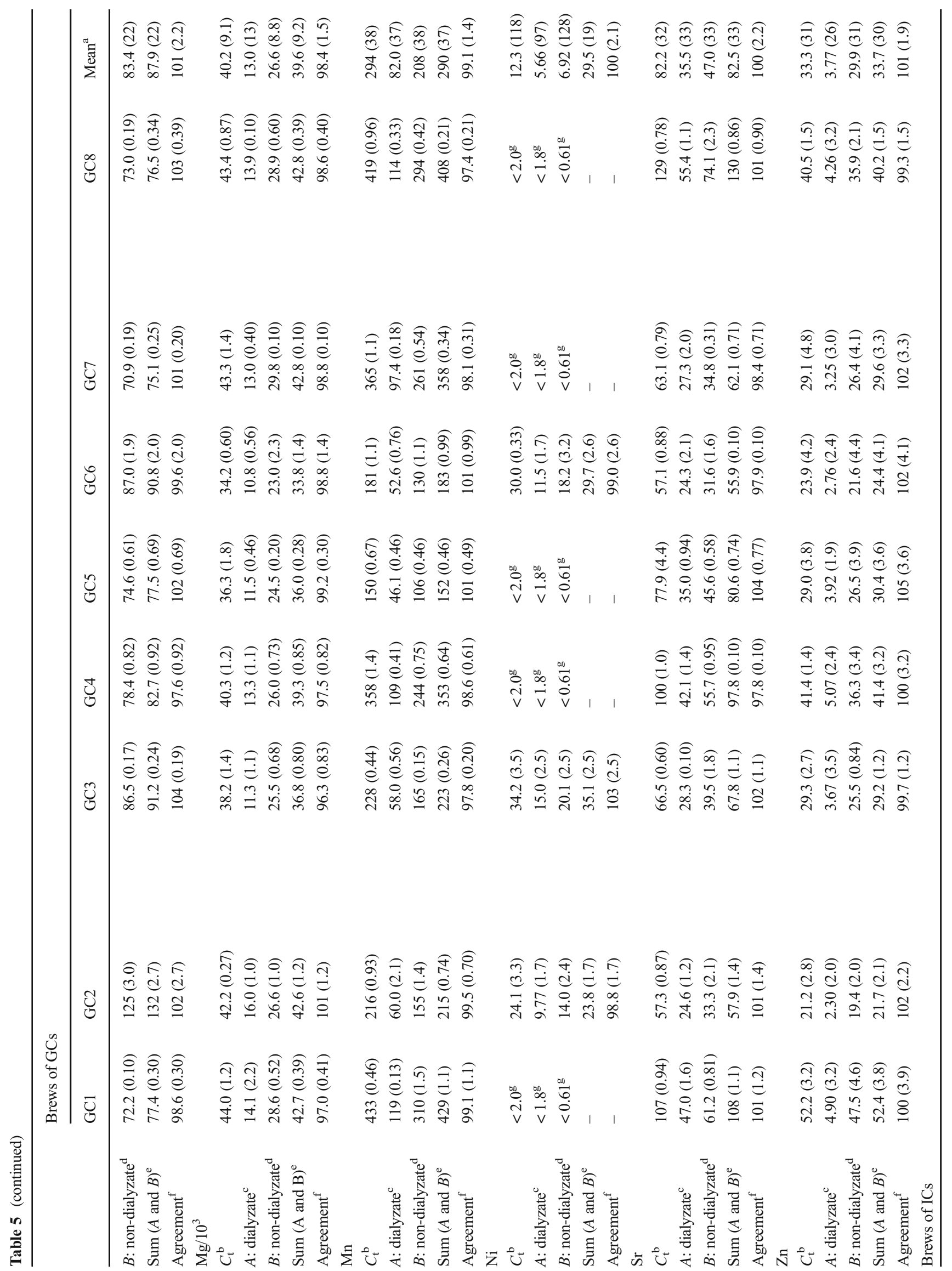




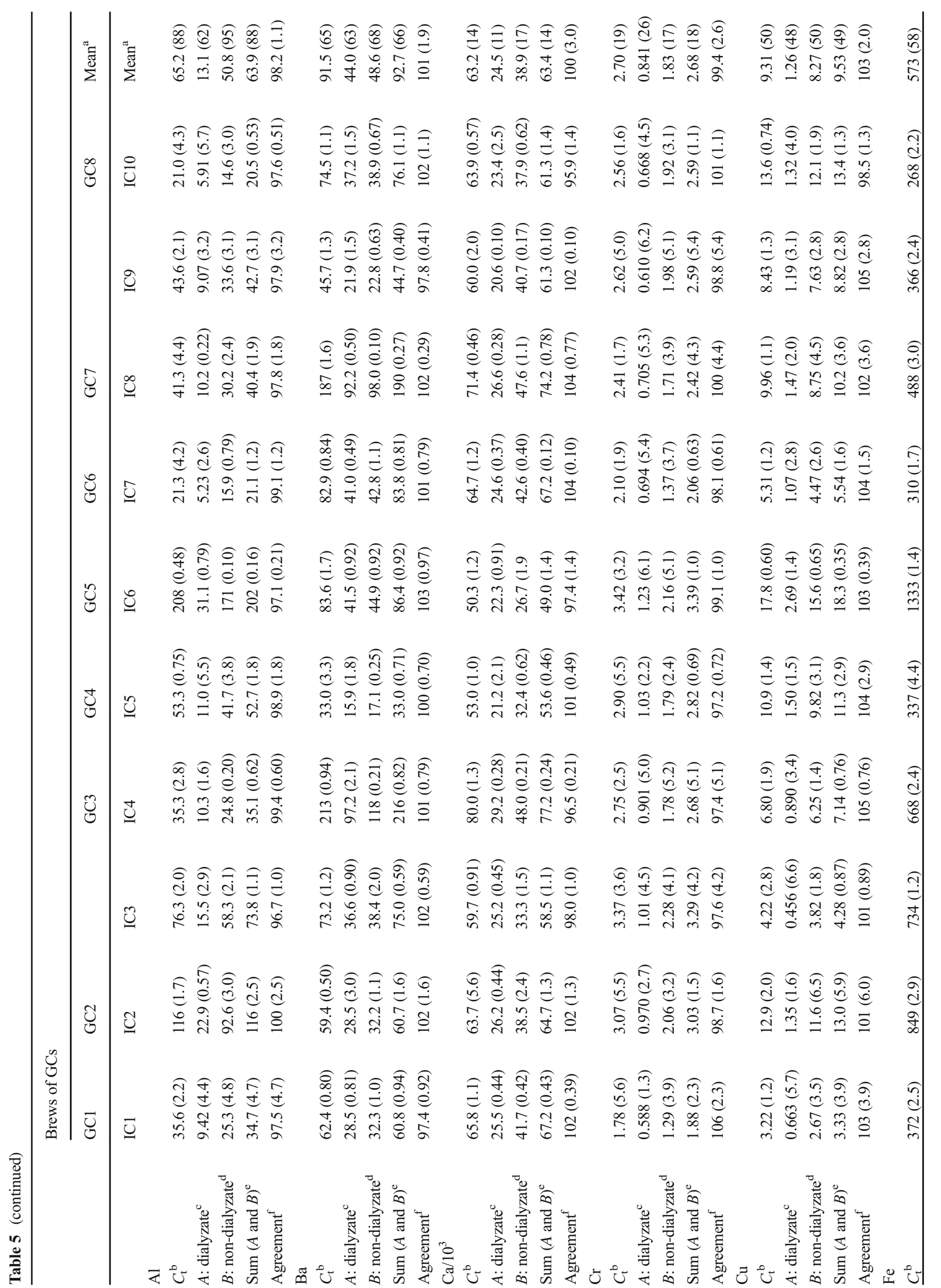




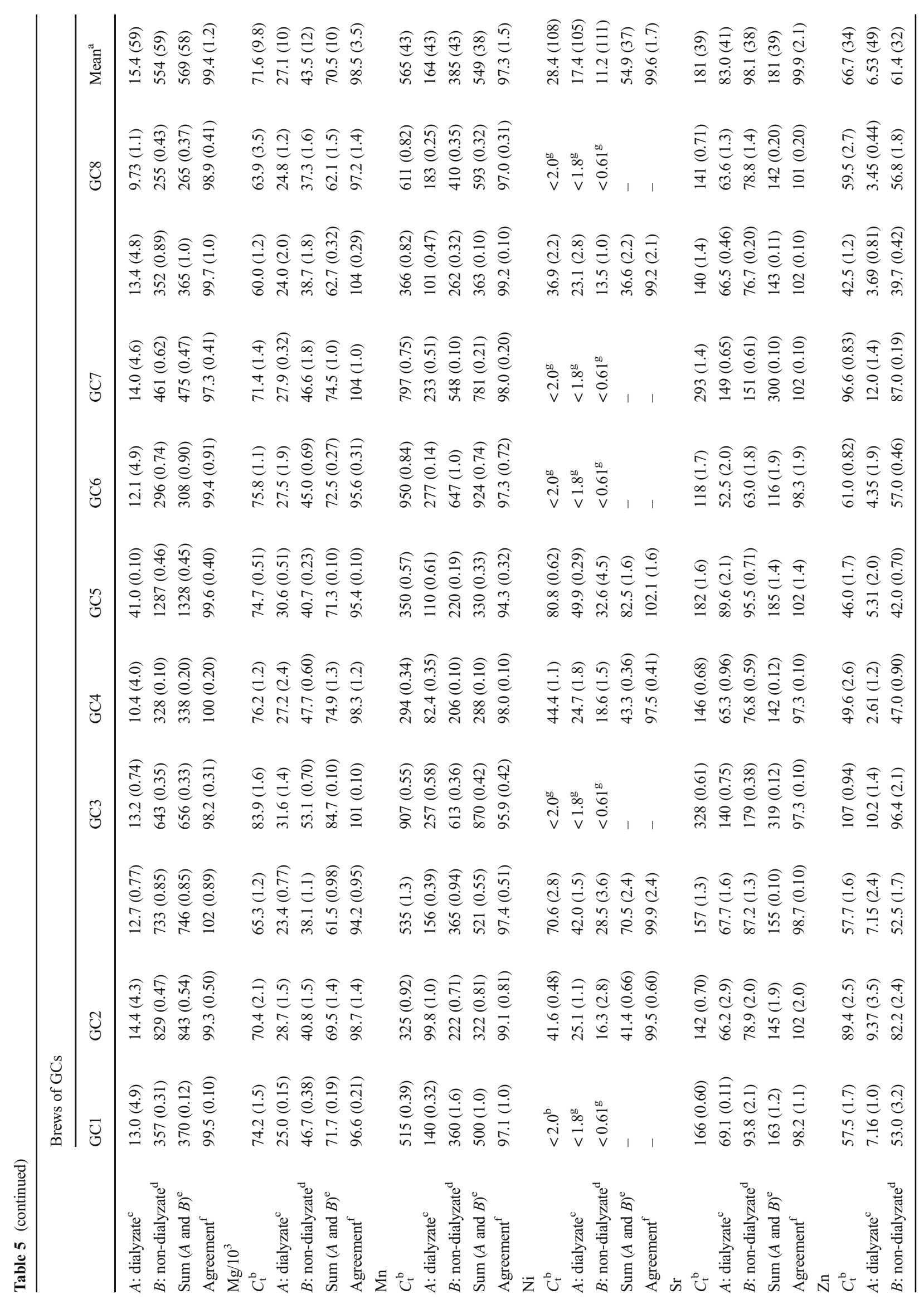




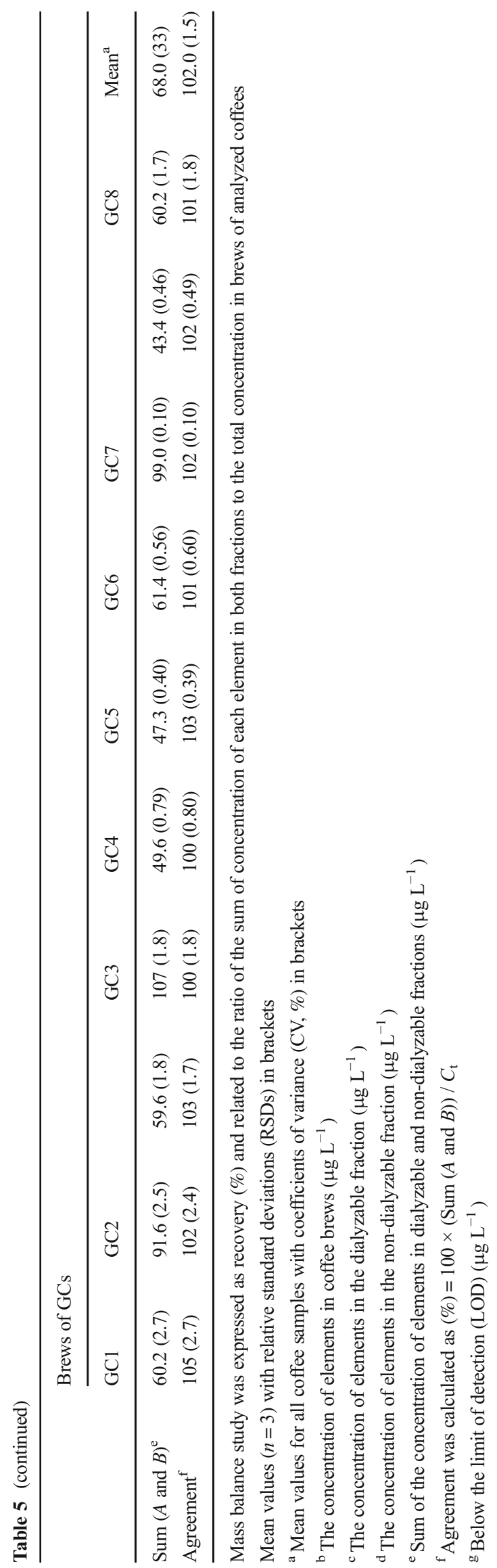

Bioaccessibility of Elements from Ground and Instant Coffee Brews

As can be seen in Table 5, in the dialyzable fraction of brews of all analyzed GCs the concentration of $\mathrm{Cr}$ was below its LOD, i.e., $<0.14 \mu \mathrm{g} \mathrm{L}^{-1}$. In several cases, the concentration of $\mathrm{Ni}$ in the dialyzable fraction of brews of GCs and ICs brews was either undetectable, i.e., $<1.8 \mu \mathrm{g} \mathrm{L}^{-1}$. Average concentrations (in $\mu \mathrm{g} \mathrm{L}^{-1}$ ) of studied 11 elements in the dialyzable fraction separated from brews of GCs and ICs, together with respective coefficients of variance $(\% \mathrm{CVs})$, were as follows: GCs [2.57 (57\%) for Al, $13.1(55 \%)$ for $\mathrm{Ba}, 7.47 \times 10^{3}(36 \%)$ for $\mathrm{Ca}, 3.11$ (18\%) for $\mathrm{Cu}, 4.43(28 \%)$ for $\mathrm{Fe}, 13.0 \times 10^{3}(13 \%)$ for $\mathrm{Mg}, 82.0$ (37\%) for $\mathrm{Mn}, 5.66$ (97\%) for Ni, 35.5 (33\%) for $\mathrm{Sr}$, and 3.77 (26\%) for $\mathrm{Zn}$ ] and ICs [13.1 (62\%) for $\mathrm{Al}, 44.0$ (63\%) for $\mathrm{Ba}, 24.5 \times 10^{3}$ (11\%) for $\mathrm{Ca}, 0.841(26 \%)$ for $\mathrm{Cr}$, $1.26(48 \%)$ for $\mathrm{Cu}, 15.4(59 \%)$ for $\mathrm{Fe}, 27.1 \times 10^{3}(10 \%)$ for $\mathrm{Mg}, 164$ (43\%) for Mn, 17.4 (105\%) for Ni, 83.0 (41\%) for $\mathrm{Sr}$, and $6.53(49 \%)$ for $\mathrm{Zn}$ ]. Elements with the lowest variation of concentrations among all examined GCs brews were $\mathrm{Cu}, \mathrm{Fe}$, $\mathrm{Mg}$, and $\mathrm{Zn}$ (CV from 13 to $28 \%$ ). The highest variability of results was established for $\mathrm{Al}, \mathrm{Ba}$, and $\mathrm{Ni}(\mathrm{CV}$ from 55 to 97\%). In case of ICs brews, the lowest variation of concentrations was assessed for $\mathrm{Ca}, \mathrm{Cr}$, and $\mathrm{Mg}$ (CV from 10 to 26\%), while the highest $\mathrm{CV}$ s were found for $\mathrm{Al}, \mathrm{Ba}, \mathrm{Fe}$, and $\mathrm{Ni}$ (59$105 \%)$.

Precision of results obtained for analysis of the dialyzable fraction of GCs brews was satisfactorily good and ranged 1.2$5.0 \%(\mathrm{Al}), 0.08-4.3 \%(\mathrm{Ba}), 0.54-3.7 \%(\mathrm{Ca}), 0.22-3.2 \%(\mathrm{Cu})$, $1.2-4.4 \%(\mathrm{Fe}), 0.10-2.2 \%(\mathrm{Mg}), 0.13-2.1 \%(\mathrm{Mn}), 1.7-2.5 \%$ (Ni), $0.10-2.1 \%(\mathrm{Sr})$, and $1.9-3.5 \%(\mathrm{Zn})$. For ICs brews, the following RSD values were obtained: $0.22-5.7 \%(\mathrm{Al}), 0.49$ $3.0 \%(\mathrm{Ba}), 0.10-2.5 \%(\mathrm{Ca}), 1.3-6.2 \%(\mathrm{Cr}), 1.4-6.6 \%(\mathrm{Cu})$, $0.10-4.9 \%(\mathrm{Fe}), 0.15-2.4 \%(\mathrm{Mg}), 0.14-1.0 \%(\mathrm{Mn}), 0.29$ $2.8 \%(\mathrm{Ni}), 0.11-2.9 \%(\mathrm{Sr})$, and $0.44-3.5 \%(\mathrm{Zn})$.

Contributions of the bioaccessible fraction of studied elements $(\%)$ were calculated as $100 \times A / C_{\mathrm{t}}$, where $A$ is their concentration (in $\mu \mathrm{g} \mathrm{L}^{-1}$ ) determined in the dialyzable fraction and $C_{\mathrm{t}}$ is their total concentration determined in brews (in $\mu \mathrm{g} \mathrm{L}^{-1}$ ). Results are presented in Table 6. Precision assessed for calculated contributions of the bioaccessible fraction of all elements varied from $0.23 \%$ ( $\mathrm{Sr}$ ) to $5.3 \%$ (Al) for GCs brews and from $0.24 \%(\mathrm{Sr})$ to $6.4 \%(\mathrm{Cu})$ in the case of ICs brews.

It was established that bioaccessibility of essential elements ( $\mathrm{Ca}, \mathrm{Cr}, \mathrm{Cu}, \mathrm{Fe}, \mathrm{Mg}, \mathrm{Mn}, \mathrm{Ni}$, and $\mathrm{Zn}$ ) from brews of GCs and ICs was rather similar and decreased in the following order: $\mathrm{Ca} \geq \mathrm{Mg}>\mathrm{Mn}>\mathrm{Cu}>\mathrm{Zn}>\mathrm{Fe}$. The exception was observed for brews of GC6 and IC9, for which different relations in bioaccessibility of mentioned essential elements were noticed, i.e., $\mathrm{Mg}>\mathrm{Mn}>\mathrm{Ca}>\mathrm{Cu}>\mathrm{Zn}>\mathrm{Fe}(\mathrm{GC} 6)$, and $\mathrm{Mg}>\mathrm{Ca}>$ $\mathrm{Mn}>\mathrm{Cu}>\mathrm{Zn}>\mathrm{Fe}$ (IC9). For non-essential elements (Al, $\mathrm{Ba}$, and $\mathrm{Sr}$ ), their bioaccessibility decreased in the following order: $\mathrm{Ba} \approx \mathrm{Sr}>\mathrm{Al}$ for $\mathrm{GCs}$ and ICs. Generally, the mean 
Table 6 Bioaccessibility of elements from brews of ground (GCs) and instant (ICs) coffees

Bioaccessibility (\%)

\begin{tabular}{|c|c|c|c|c|c|c|c|c|c|c|}
\hline \multicolumn{11}{|c|}{ Brews of GCs } \\
\hline & $\mathrm{GC} 1$ & $\mathrm{GC} 2$ & GC3 & GC4 & GC5 & GC6 & GC7 & \multicolumn{3}{|l|}{ GC 8} \\
\hline $\mathrm{Al}$ & $15.0 \pm 0.8$ & $15.0 \pm 0.6$ & $17.0 \pm 0.6$ & $19.0 \pm 0.5$ & $26.5 \pm 0.3$ & $23.9 \pm 0.3$ & $19.9 \pm 0.3$ & \multicolumn{3}{|l|}{$15.7 \pm 0.3$} \\
\hline $\mathrm{Ba}$ & $43.4 \pm 0.6$ & $40.8 \pm 1.0$ & $43.6 \pm 0.6$ & $43.7 \pm 0.4$ & $42.2 \pm 0.1$ & $42.8 \pm 0.2$ & $41.6 \pm 0.8$ & \multicolumn{3}{|l|}{$44.0 \pm 1.9$} \\
\hline $\mathrm{Ca}$ & $37.2 \pm 1.4$ & $40.7 \pm 1.5$ & $35.9 \pm 0.2$ & $34.0 \pm 0.3$ & $32.4 \pm 0.4$ & $28.6 \pm 1.0$ & $35.3 \pm 0.2$ & \multicolumn{3}{|l|}{$36.1 \pm 0.5$} \\
\hline $\mathrm{Cr}$ & - & - & - & - & - & - & - & \multicolumn{3}{|l|}{ - } \\
\hline $\mathrm{Cu}$ & $13.6 \pm 0.3$ & $13.5 \pm 0.4$ & $18.6 \pm 0.1$ & $12.4 \pm 0.3$ & $14.6 \pm 0.1$ & $13.8 \pm 0.4$ & $14.9 \pm 0.2$ & \multicolumn{3}{|l|}{$19.0 \pm 0.5$} \\
\hline $\mathrm{Fe}$ & $6.68 \pm 0.23$ & $5.35 \pm 0.18$ & $5.38 \pm 0.09$ & $5.10 \pm 0.13$ & $3.76 \pm 0.11$ & $4.12 \pm 0.18$ & $5.62 \pm 0.07$ & \multicolumn{3}{|l|}{$4.65 \pm 0.16$} \\
\hline $\mathrm{Mg}$ & $32.0 \pm 0.7$ & $37.9 \pm 0.4$ & $29.6 \pm 0.3$ & $33.0 \pm 0.4$ & $31.7 \pm 0.1$ & $31.6 \pm 0.2$ & $30.0 \pm 0.1$ & \multicolumn{3}{|l|}{$32.0 \pm 0.1$} \\
\hline $\mathrm{Mn}$ & $27.5 \pm 0.1$ & $27.8 \pm 0.6$ & $25.4 \pm 0.1$ & $30.4 \pm 0.1$ & $30.7 \pm 0.1$ & $29.1 \pm 0.2$ & $26.7 \pm 0.1$ & \multicolumn{3}{|l|}{$27.2 \pm 0.1$} \\
\hline $\mathrm{Ni}$ & - & $40.5 \pm 0.7$ & $43.9 \pm 1.1$ & - & - & $38.3 \pm 0.6$ & - & \multicolumn{3}{|l|}{ - } \\
\hline $\mathrm{Sr}$ & $43.9 \pm 0.7$ & $42.9 \pm 0.5$ & $42.6 \pm 0.1$ & $42.1 \pm 0.6$ & $44.9 \pm 0.4$ & $42.6 \pm 0.9$ & $43.3 \pm 0.9$ & \multicolumn{3}{|l|}{$43.0 \pm 0.5$} \\
\hline $\mathrm{Zn}$ & $9.39 \pm 0.30$ & $10.8 \pm 0.2$ & $12.5 \pm 0.4$ & $12.2 \pm 0.3$ & $13.5 \pm 0.3$ & $11.6 \pm 0.3$ & $11.2 \pm 0.3$ & \multicolumn{3}{|l|}{$10.5 \pm 0.3$} \\
\hline \multicolumn{11}{|c|}{ Brews of ICs } \\
\hline & IC1 & IC2 & IC3 & IC4 & IC5 & IC6 & IC7 & IC8 & IC9 & IC10 \\
\hline $\mathrm{Al}$ & $26.5 \pm 1.2$ & $19.7 \pm 0.1$ & $20.3 \pm 0.6$ & $29.2 \pm 0.5$ & $20.6 \pm 1.1$ & $15.0 \pm 0.1$ & $24.6 \pm 0.6$ & $24.7 \pm 0.1$ & $20.8 \pm 0.7$ & $28.1 \pm 1.6$ \\
\hline $\mathrm{Ba}$ & $45.7 \pm 0.4$ & $48.0 \pm 1.4$ & $50.0 \pm 0.4$ & $45.6 \pm 1.0$ & $48.2 \pm 0.9$ & $49.6 \pm 0.4$ & $49.5 \pm 0.2$ & $49.3 \pm 0.2$ & $47.9 \pm 0.7$ & $49.9 \pm 0.7$ \\
\hline $\mathrm{Ca}$ & $38.7 \pm 0.2$ & $41.1 \pm 0.2$ & $42.2 \pm 0.2$ & $36.5 \pm 0.1$ & $40.0 \pm 0.8$ & $44.3 \pm 0.4$ & $38.0 \pm 0.1$ & $37.3 \pm 0.1$ & $34.3 \pm 0.1$ & $36.6 \pm 0.9$ \\
\hline $\mathrm{Cr}$ & $33.2 \pm 0.4$ & $31.6 \pm 1.2$ & $30.0 \pm 1.3$ & $32.7 \pm 1.6$ & $35.5 \pm 0.8$ & $36.0 \pm 2.2$ & $33.1 \pm 1.8$ & $29.2 \pm 1.6$ & $23.3 \pm 1.4$ & $26.2 \pm 1.2$ \\
\hline $\mathrm{Cu}$ & $20.5 \pm 1.2$ & $10.5 \pm 0.2$ & $10.9 \pm 0.7$ & $13.1 \pm 0.4$ & $13.8 \pm 0.2$ & $15.1 \pm 0.2$ & $20.2 \pm 0.6$ & $14.8 \pm 0.3$ & $14.1 \pm 0.4$ & $9.71 \pm 0.39$ \\
\hline $\mathrm{Fe}$ & $3.49 \pm 0.17$ & $1.70 \pm 0.07$ & $1.73 \pm 0.01$ & $1.98 \pm 0.02$ & $3.09 \pm 0.12$ & $3.08 \pm 0.01$ & $3.90 \pm 0.19$ & $2.87 \pm 0.13$ & $3.66 \pm 0.18$ & $3.63 \pm 0.04$ \\
\hline $\mathrm{Mg}$ & $33.7 \pm 0.1$ & $40.8 \pm 0.6$ & $35.8 \pm 0.3$ & $37.7 \pm 0.5$ & $35.7 \pm 0.8$ & $41.0 \pm 0.2$ & $36.3 \pm 0.7$ & $39.1 \pm 0.1$ & $40.0 \pm 0.8$ & $38.8 \pm 0.5$ \\
\hline $\mathrm{Mn}$ & $27.2 \pm 0.1$ & $30.7 \pm 0.3$ & $29.2 \pm 0.1$ & $28.3 \pm 0.2$ & $28.0 \pm 0.1$ & $31.4 \pm 0.2$ & $29.2 \pm 0.1$ & $29.2 \pm 0.1$ & $27.6 \pm 0.1$ & $30.0 \pm 0.1$ \\
\hline $\mathrm{Ni}$ & - & $60.3 \pm 0.7$ & $59.5 \pm 0.9$ & - & $55.6 \pm 1.0$ & $61.8 \pm 0.2$ & - & - & $62.6 \pm 1.8$ & - \\
\hline $\mathrm{Sr}$ & $41.6 \pm 0.1$ & $46.6 \pm 1.4$ & $43.1 \pm 0.7$ & $42.7 \pm 0.3$ & $44.7 \pm 0.4$ & $49.2 \pm 1.0$ & $44.5 \pm 0.9$ & $50.8 \pm 0.3$ & $47.5 \pm 0.2$ & $45.1 \pm 0.6$ \\
\hline $\mathrm{Zn}$ & $12.5 \pm 0.1$ & $10.5 \pm 0.4$ & $12.4 \pm 0.3$ & $9.53 \pm 0.13$ & $5.26 \pm 0.06$ & $11.5 \pm 0.2$ & $7.13 \pm 0.14$ & $12.4 \pm 0.2$ & $8.68 \pm 0.07$ & $5.80 \pm 0.03$ \\
\hline
\end{tabular}

Mean values $(n=3) \pm$ standard deviation

contribution of the bioaccessible fraction of all examined elements was considerably lower than $50 \%$. Only for $\mathrm{Ni}$, the average contribution of this fraction was about $60 \%$. Bioaccessibility of elements evaluated in brews of GCs was lower than this determined in ICs brews for $\mathrm{Al}(21 \%), \mathrm{Ba}$ (13\%), Ca (11\%), Cu (5\%), Mg (18\%), Mn (4\%), Ni (47\%), and $\mathrm{Sr}(6 \%)$. In case of $\mathrm{Fe}$ and $\mathrm{Zn}$, contributions of the bioaccessible fraction of these elements assessed for GCs brews were higher by about $47 \%$ and $17 \%$, respectively, than these evaluated in ICs brews.

Among essential elements studied, the highest mean contribution of the bioaccessible fraction was assessed for $\mathrm{Ni}$, i.e., $40.0 \%$ (CV of $6.8 \%$ ) in case of brews of GC2, GC3, GC6, and $60.0 \%$ (CV of $4.0 \%$ ) for five different ICs brews (IC2, IC3, IC5, IC6, IC9). Chromium was determined only in bioaccessible fraction of ICs brews and its bioaccessibility changed from 23.3 to $36.0 \%$ (with a mean value of $31.1 \%$ and $\mathrm{CV}$ of $12 \%)$. The mean contribution of the bioaccessible fraction of $\mathrm{Ca}$ was moderate and equal $35.0 \%$ (CV of $10 \%$ ) for brews of GCs and $38.9 \%$ (CV of $7.2 \%$ ) for brews of ICs. Results achieved here for $\mathrm{Ca}$ for brews of GCs were $\sim 20 \%$ lower than those obtained for brews of different GCs (Stelmach et al. 2014) and slim coffees (Szymczycha-Madeja et al. 2015). In case of ICs, our results were lower than those reported in earlier studies by Szymczycha-Madeja et al. (2015) for slim coffees $(\sim 13 \%)$ and Stelmach et al. (2016) for brews of different ICs $(\sim 22 \%)$. Bioaccessibility of $\mathrm{Mg}$ of $32.2 \%$ (CV of $7.8 \%$ ) and $37.9 \%$ (CV of $6.1 \%$ ), obtained for brews of GCs and ICs, respectively, was $25 \%$ lower than this obtained for $\mathrm{Ca}$. They were also about two times lower than those reported for $\mathrm{Mg}$ for different coffees (Stelmach et al. 2014, 2016; Szymczycha-Madeja et al. 2015), chocolate drink powder (Peixoto et al. 2013) and herbal remedies (Szentmihayli et al. 2006). Mean bioaccessibility of Mn from GCs and ICs brews was practically the same, i.e., $28.1 \%$ (CV of $6.4 \%$ ) and $29.1 \%$ (CV of $4.5 \%$ ), respectively, but lower than this established for $\mathrm{Ca}$ and $\mathrm{Mg}$. In addition, the contribution of the bioaccessible fraction of Mn in brews of ICs was slightly lower than this reported by other authors for brews of different ICs, i.e., $40.6 \%$ (CV of 25\%) (Stelmach et al. 2016), but 
comparable with this determined for slim coffees, i.e., $28.4 \%$ (CV of 18\%) (Szymczycha-Madeja et al. 2015). The reason for such differences between our results and those reported by others for brews of GCs and ICs coffees (Stelmach et al. 2014, 2016) can probably be attributed to various approaches used to simulate absorption in the villi. Moreover, it can be also due to high variability in the contribution of bioaccessible fractions of elements in brews of different coffees (reflecting by high values of $\% \mathrm{CV}$ obtained in cited works). Nevertheless, results obtained for $\mathrm{Mn}$ in brews of GCs were in good agreement with those reported for different GCs by Stelmach et al. (2014), where $26.8 \%$ (CV of $43 \%$ ) bioaccessibility of Mn was established. In case of $\mathrm{Cu}$, its bioaccessibility was relatively low and quite similar for both coffee types, i.e., $15.0 \%$ (CV of $16 \%$ ) for GCs and $14.3 \%$ (CV of 24\%) for ICs. These results were comparable to those obtained for cashew apple juice (de Lima et al. 2014), but much lower than those determined for slim coffees (Szymczycha-Madeja et al. 2015), tea infusions (Powell et al. 1998), and chocolate drink powder (Peixoto et al. 2013). An average contribution of the bioaccessible fraction of $\mathrm{Zn}$, i.e., $11.5 \%$ (CV of $11 \%$ ) for brews of GCs and 9.57\% (CV of 27\%) for brews of ICs, showed that this element was poorly bioaccessible from coffees. Additionally, results obtained for $\mathrm{Zn}$ were significantly lower than those obtained for slim coffees (Szymczycha-Madeja et al. 2015), tea infusions (Powell et al. 1998), herbal remedies (Szentmihayli et al. 2006), and infusions/decoctions of cat's claw teas (Pereira Junior et al. 2018). In all analyzed coffees, bioaccessibility of Fe was the lowest among all studied elements and varied from 3.76 to $6.68 \%$ for brews of GCs and from 1.70 to $3.90 \%$ for brews of ICs. The mean contribution of the bioaccessible fraction of this element was $5.08 \%$ (CV of $18 \%$ ) and $2.91 \%$ (CV of 27\%) for brews of GCs and ICs, respectively. These results achieved for $\mathrm{Fe}$ for brews of GCs were more than one order of magnitude lower than those reported lately by Stelmach et al. (2014). In case of ICs, they were in good agreement with those previously reported for brews of different ICs (Stelmach et al. 2016) and slim coffees (SzymczychaMadeja et al. 2015).

Non-essential elements (Ba and $\mathrm{Sr}$ ) were moderately bioaccessible from brews of analyzed coffees because mean contributions of their bioaccessible fraction separated from GCs were comparable and equal $42.8 \%$ (CV of $2.6 \%$ ) and $43.2 \%$ (CV of $2.1 \%$ ), respectively. In case of ICs, slightly higher values than these for GCs were obtained, i.e. $48.4 \%$ (CV of $2.6 \%$ ) for $\mathrm{Ba}$ and $45.6 \%$ (CV of 2.6\%) for Sr. Results for $\mathrm{Ba}$ were higher than those reported by Szymczycha-Madeja et al. (2015) for slim coffees (34.2\%), Szentmihayli et al. (2006) for herbal remedies (28.4\%) and Peixoto et al. (2013) for chocolate drink powder (9\%). Bioaccessibility of $\mathrm{Sr}$ was in good agreement with this described for slim coffees (46.8\%) (Szymczycha-Madeja et al. 2015). The contribution of the bioaccessible fraction of $\mathrm{Al}$ was relatively low and varied from 15.0 to $26.5 \%$ (with a mean value of $19.0 \%$ and $\mathrm{CV}$ of $23 \%$ ) for brews of GCs and from 15.0 to $28.1 \%$ (with a mean value of $23.0 \%$ and $\mathrm{CV}$ of $18 \%$ ) for brews of ICs. Bioaccessibility of $\mathrm{Al}$ from brews of GCs and ICs analyzed here was about four times higher than this from tea infusions (Powell et al. 1998) and chocolate drink powder (Peixoto et al. 2013).

It can be concluded that bioaccessibility of elements from coffees was quite low. It was probably caused by the composition of coffee, chemical forms of elements, nutrients' interactions including inter-element and element-organic content relations, and presence of inhibitors, e.g., phytates, dietary fibers, proteins of plant origin, oxalates, and polyphenols (Hunt 2003; Vitali et al. 2008). Our results were in agreement with those reported lately by Pohl et al. (2016) for physical fractionation of elements in brews of corresponding GCs and ICs. They established that elements such as $\mathrm{Al}, \mathrm{Cu}$, and $\mathrm{Fe}$ were mostly associated with the highest molecular weight (MW) fraction (">100 kDa") dissolved in coffee brews. This indicated that $\mathrm{Al}, \mathrm{Cu}$, and $\mathrm{Fe}$ had likely reduced bioaccessibility because were strongly bound with high MW species through hydroxyl, carbohylate, or phenolate groups, while intestinal absorption of such species is recognized to be significantly decreased (Powell et al. 1998). Moreover, low bioaccessibility of Fe was likely attributed to presence of polyphenols, which are also acknowledged to avidly bind trivalent ions of $\mathrm{Fe}$ and prevent their intestinal absorption (Powell et al. 1998). Phytates have a strong negative influence on absorption of $\mathrm{Ca}, \mathrm{Cu}, \mathrm{Fe}, \mathrm{Mg}, \mathrm{Mn}$, and $\mathrm{Zn}$ because they willingly form insoluble salts with ions of these elements or co-precipitate as phytate complexes (Kumar et al. 2010). This could be the case of brews of studied GCs and ICs as well.

\section{Multivariate Data Exploration by Principle Component Analysis}

In case of total concentrations of studied elements, both PCs accounted for $84.7 \%$ of total variance in the data. Distribution of samples (brews of GCs and ICs) on the plane of the PC1 and the PC2 is given in Fig. 1a. As can be seen, there is a clear separation of GCs from ICs. Accordingly, GCs occupied the space with the negative values of the PC1, while samples of ICs formed a broad but separate cluster with the positive values of the PC1. Interestingly, the concentration of $\mathrm{Cu}$ was highly negatively correlated $(-0.78)$ with the $\mathrm{PC} 1$ and highly positively correlated with brews of GCs. On the other hand, concentrations of $\mathrm{Ba}(0.82), \mathrm{Ca}(0.94), \mathrm{Cr}(0.79), \mathrm{Fe}(0.77)$, $\mathrm{Mg}$ (0.95), Sr (0.88), and Zn (0.87) were highly positively correlated with the PC1 (correlation coefficients are given in brackets) and highly positively correlated with brews of ICs. For that reason, it was verified in the next turn if the information about the concentration of $\mathrm{Cu}$ and another element would enable to separate brews of GCs from ICs. Indeed, it was 
Fig. 1 Scatter plots of both principal components (PC1-PC2) extracted from data matrices based on a total concentrations of elements determined in brews of ground (GCs) and instant (ICs) coffees and $\mathbf{b}$ concentrations of elements determined in the bioaccessible fraction separated from these brews
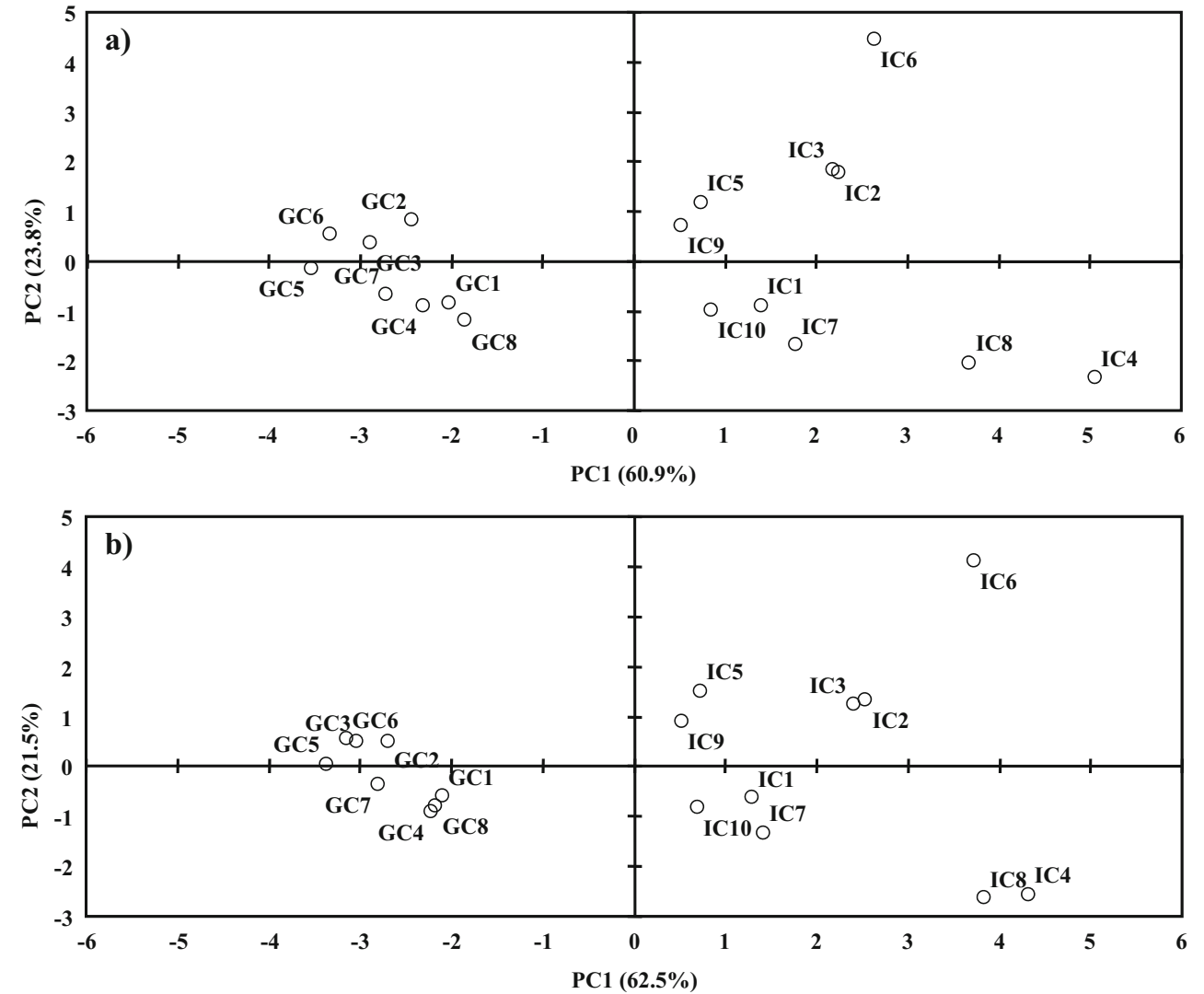

established that PCA carried out on the basis of matrices of the concentration of $\mathrm{Cu}$ along with the concentration of $\mathrm{Cr}$, $\mathrm{Mg}$, or $\mathrm{Sr}$ only as variables allowed to separate brews of GCs from ICs. The variability explained by PCA for the data matrices based on the couples of the total concentration of $\mathrm{Cu}$ and $\mathrm{Cr}$, $\mathrm{Cu}$ and $\mathrm{Mg}$, or $\mathrm{Cu}$ and $\mathrm{Sr}$ was $100 \%$. In this case, the total concentration of both elements in brews of GCs and ICs were highly correlated (correlation coefficients are given) with the PC1, i.e., -0.88 and 0.88 for $\mathrm{Cu}$ and $\mathrm{Cr}$, respectively; -0.95 and 0.95 for $\mathrm{Cu}$ and $\mathrm{Mg}$, respectively; and -0.90 and 0.90 for $\mathrm{Cu}$ and $\mathrm{Sr}$, respectively.

Concentrations of $\mathrm{Al}, \mathrm{Ba}, \mathrm{Ca}, \mathrm{Co}, \mathrm{Cr}, \mathrm{Cu}, \mathrm{Fe}, \mathrm{Mg}, \mathrm{Mn}, \mathrm{Ni}$, $\mathrm{Pb}, \mathrm{Sr}$, and $\mathrm{Zn}$ determined in the bioaccessible fraction assessed for brews of GCs and ICs were also used as variables for PCA. The plot visualizing brews of GCs and ICs on the scatter of the PC1 versus PC2 is given in Fig. 1b. Both extracted PCs were established to account for $84.0 \%$ of total variance in the data. Similarly as in case of total concentrations used as variables, concentrations of elements in the bioaccessible fraction allowed to clearly separate GCs from ICs. In this case, all brews of GCs had negative values of the PC1, while all brews of ICs had positive values of the PC1. Again, it was also found that the concentration of $\mathrm{Cu}$ in the bioaccessible fraction was highly positively correlated with brews of GCs and highly negatively correlated with the PC1 $(-0.77)$. On the other hand, concentrations of $\mathrm{Al}(0.75), \mathrm{Ba}(0.81), \mathrm{Ca}$ (0.94), Cr (0.91), Fe (0.73), Mg (0.96), Sr (0.86), and Zn
(0.73) in the bioaccessible fraction were highly positively correlated with the PC1 (correlation coefficients are given in brackets) and brews of ICs. Hence, it was tried to find respective couples of elements (one was $\mathrm{Cu}$ ), which concentrations determined in the bioaccessible fraction would enable to group brews of GCs and ICs into two separate clusters by means of PCA. It was established that except for $\mathrm{Cr}, \mathrm{Mg}$, and $\mathrm{Sr}$, also $\mathrm{Al}, \mathrm{Ca}$, and $\mathrm{Fe}$ could be used along with $\mathrm{Cu}$ for successful grouping of brewed GCs and ICs according to information on the concentration of these elements in the bioaccessible fraction. In this case, all couples of elements, i.e., $\mathrm{Cu}$ $\mathrm{Al}, \mathrm{Cu}-\mathrm{Ca}, \mathrm{Cu}-\mathrm{Cr}, \mathrm{Cu}-\mathrm{Fe}, \mathrm{Cu}-\mathrm{Mg}$, and $\mathrm{Cu}-\mathrm{Sr}$, enabled to clearly separate brews of GCs from ICs. In this case, the concentration of both elements in the bioaccessible fraction were highly correlated (correlation coefficients are given) with the PC1, i.e., -0.84 and 0.84 for $\mathrm{Cu}$ and $\mathrm{Al}$, respectively; -0.96 and 0.95 for $\mathrm{Cu}$ and $\mathrm{Ca}$, respectively; and -0.92 and 0.92 for $\mathrm{Cu}$ and $\mathrm{Cr}$, respectively; -0.81 and 0.81 for $\mathrm{Cu}$ and $\mathrm{Fe}$, respectively; -0.94 and 0.94 for $\mathrm{Cu}$ and $\mathrm{Mg}$, respectively; and -0.88 and 0.88 for $\mathrm{Cu}$ and $\mathrm{Sr}$, respectively.

\section{Conclusion}

In this work, for the first time, a simple method of F AAS and ICP OES analysis of brews of ground and instant coffees after in vitro gastrointestinal digestion on concentrations of 
essential ( $\mathrm{Ca}, \mathrm{Cr}, \mathrm{Cu}, \mathrm{Fe}, \mathrm{Mg}, \mathrm{Mn}, \mathrm{Ni}, \mathrm{Zn})$ and non-essential (Al, Ba, Sr) elements was developed and fully validated. It was found that direct analysis of resulting dialyzable and nondialyzable fractions of coffee brews was reliable and significantly reduced time of analysis, and completely eliminated risk of sample contamination and loss of analytes commonly possible when conventional wet digestion is used.

Results of in vitro gastrointestinal digestion indicated that the mean contribution of the bioaccessible fraction of all examined elements from ground and instant coffees was generally low, i.e., [5.08-40.9\% (GCs) and 2.91-60.0\% (ICs)] and [19.0-43.2\% (GCs) and 23.0-48.4\% (ICs)] for essential and non-essential elements, respectively. This low bioaccessibility could be due to the fact that these elements are strongly affected by matrix constituents.

PCA of brews of all analyzed coffees, carried out on the basis of total concentrations of elements and their concentrations in the bioaccessible fraction separated from brews, showed that information about composition and bioaccessibility of elements in brews of GCs and ICs can be help in their classification and discrimination according to their type.

Acknowledgments The authors acknowledge the statutory activity subsidy from Polish Ministry of Science and Higher Education for the Faculty of Chemistry, Wroclaw University of Technology.

Funding This study was funded by the National Science Centre of Poland (grant number 2013/09/B/NZ9/00122).

\section{Compliance with Ethical Standards}

Conflict of Interest Anna Szymczycha-Madeja declares that she has no conflict of interest. Maja Welna declares that she has no conflict of interest. Pawel Pohl declares that he has no conflict of interest.

Ethical Approval This article does not contain any studies with human or animal subjects.

\section{Informed Consent Not applicable.}

Open Access This article is distributed under the terms of the Creative Commons Attribution 4.0 International License (http:// creativecommons.org/licenses/by/4.0/), which permits unrestricted use, distribution, and reproduction in any medium, provided you give appropriate credit to the original author(s) and the source, provide a link to the Creative Commons license, and indicate if changes were made.

\section{References}

Bermejo P, Pena EM, Dominguez R, Bermejo A, Cocho JA, Fraga JM (2002) Iron and zinc in hydrolised fractions of human milk and infant formulas using an in vitro method. Food Chem 77:361-369

Camara F, Amaro MA, Barbera R, Clemente G (2005) Bioaccessibility of minerals in school meals: comparison between dialysis and solubility methods. Food Chem 92:481-489
Cautela D, Santelli F, Boscaino F, Laratta B, Servilloe L, Castaldof D (2009) Elemental content and nutritional study of blood orange juice. J Sci Food Agric 89:2283-2291

Chaiwanon P, Puwastien P, Nitithamyong A, Sirichakwal PP (2000) Calcium fortification in soybean milk and in vitro bioavailability. $\mathrm{J}$ Food Compos Anal 13:319-327

de Lima ACS, Soares DJ, da Silva LMR, de Figueiredo RW, de Sousa PHM, de Abreu Menezes E (2014) In vitro bioaccessibility of cooper, iron, zinc and antioxidant compounds of whole cashew apple juice and cashew apple fibre (Anacardium occidentale L.) following simulated gastro-intestinal digestion. Food Chem 161:142-147

do Nascimento da Silva E, Heerdt G, Cidade M, Diniz Pereira C, Morgon $\mathrm{NH}$, Cadore S (2015) Use of in vitro digestion method and theoretical calculations to evaluate the bioaccessibility of $\mathrm{Al}, \mathrm{Cd}, \mathrm{Fe}$ and $\mathrm{Zn}$ in lettuce and cole by inductively coupled plasma mass spectrometry. Microchem J 119:152-158

do Nascimento da Silva E, de Farias LO, Cadore S (2017) The total concentration and bioaccessible fraction of nutrients in purées, instant cereals and infant formulas by ICP OES: a study of dietary recommended intakes and the importance of using a standardized in vitro digestion method. J Food Comp Anal 68:65-72. https://doi. org/10.1016/j.jfca.2017.06.007

Dominguez-Gonzalez R, Romarís-Hortas V, García-Sartal C, MoredaPiñeiro A, del Carmen Barciela-Alonso M, Bermejo-Barrera P (2010) Evaluation of an in vitro method to estimate trace elements bioavailability in edible seaweeds. Talanta 98:1668-1673

Ekmekcioglu C (2002) A physiological approach for preparing and conducting intestinal bioavailability studies using experimental systems. Food Chem 76:225-230

Erdemir US (2018) Contribution of tea (Camellia sinensis L.) to recommended daily intake of $\mathrm{Mg}, \mathrm{Mn}$ and $\mathrm{Fe}$ : an in vitro bioaccessibility assessment. J Food Compos Anal 69:71-77

García-Sartal C, Romarís-Hortas V, del Carmen Barciela-Alonso M, Moreda-Piñeiro A, Dominguez-Gonzalez R, Bermejo-Barrera P (2011) Use of an in vitro digestion method to evaluate the bioaccessibility of arsenic in edible seaweed by inductively coupled plasmamass spectrometry. Microchem J 98:91-96

García-Sartal C, del Carmen Barciela-Alonso M, Moreda-Piñeiro A, Dominguez-Gonzalez R, Bermejo-Barrera P (2013) Study of cooking on the bioavailability of $\mathrm{As}, \mathrm{Co}, \mathrm{Cr}, \mathrm{Cu}, \mathrm{Fe}, \mathrm{Ni}$, Se and $\mathrm{Zn}$ from edible seaweed. Microchem J 108:92-99

Gawlik-Dziki U, Dziki D, Baraniak B, Lin R (2009) The effect of simulated digestion in vitro on bioactivity of wheat bread with Tartary buckwheat flavones addition. LWT Food Sci Technol 42:137-143

Grembecka M, Malinowska E, Szefer P (2007) Differentiation of market coffee and its infusions in view of their mineral composition. Sci Total Environ 383:59-69

Haro-Vicente JF, Martinez-Gracia C, Ros G (2006) Optimisation of in vitro measurement of available iron from different fortificants in citric fruit juices. Food Chem 98:639-648

Hunt JR (2003) Bioavailability of iron, zinc, and other trace minerals from vegetarian diets. Am J Clin Nutr 78:633S-639S

Hur SJ, Lim BO, Decker EA, McClements DJ (2011) In vitro human digestion models for food application. Food Chem 125:1-12

Intawongse M, Dean JR (2006) In-vitro testing for assessing oral bioaccessibility of trace metals in soil and food samples. Trends Anal Chem 9:876-886

Khouzam RB, Pohl P, Lobinski R (2011) Bioaccessibility of essential elements from white cheese, bread, fruit and vegetables. Talanta $86: 425-428$

Konieczka P, Namiesnik J (2009) Quality assurance and quality control in the analytical chemical laboratory: a practical approach. CRC Press, Boca Raton

Kumar V, Sinha AK, Makkar PS, Becker K (2010) Dietary roles of phytate and phytase in human nutrition: a review. Food Chem 120:945-959 
Lamsal RP, Beauchemin D (2015) Estimation of the bio-accessible fraction of $\mathrm{Cr}, \mathrm{As}, \mathrm{Cd}$ and $\mathrm{Pb}$ in locally available bread using on-line continuous leaching method coupled to inductively coupled plasma mass spectrometry. Anal Chim Acta 867:9-17

Machado I, Cesio MV, Piston M (2017) In vitro bioaccessibility study of $\mathrm{As}, \mathrm{Cd}, \mathrm{Cu}, \mathrm{Fe}, \mathrm{Ni}, \mathrm{Pb}$ and $\mathrm{Zn}$ from raw edible artichoke heads (Cynara cardunculus L. subsp. Cardunculus). Microchem J 133: 663-668

Menezes EA, Oliveira AF, Franca CJ, Souza GB, Nogueira AR (2018) Bioaccessibility of $\mathrm{Ca}, \mathrm{Cu}, \mathrm{Fe}, \mathrm{Mg}, \mathrm{Zn}$, and crude protein in beef, pork and chicken after thermal processing. Food Chem 240:75-83

Oliveira M, Casal S, Morais S, Alves C, Dias F, Ramos S, Mendes E, Delerue-Matosa C, Oliveira MBPP (2012) Intra- and interspecific mineral composition variability of commercial coffees and coffee substitutes. Contribution to mineral intake. Food Chem 130:702709

Oliveira AP, Mateo BSO, Fioroto AM, Oliveira PV, Naozuka J (2018) Effect of cooking on the bioaccessibility of essential elements in different varieties of beans (Phaseolus vulgaris L.). J Food Compos Anal 67:135-140

Peixoto RRA, Mazon EAM, Cadore S (2013) Estimation of the bioaccessibility of metallic elements in chocolate drink powder using in vitro digestion method and spectrometric techniques. J Braz Chem Soc 24:884-890

Pereira Junior JB, Brito RCM, Pereira LPB, Fernandes Dantas KG (2018) Assessment of the bioaccessibility of trace elements in cat's claw teas by in vitro simulated gastrointestinal digestion using FAAS. Biol Trace Elem Res 182:178-184

Pereira CC, do Nascimento da Silva E, de Souza AO, Vieira MA, Ribeiro AS, Cadore S (2016) Evaluation of the bioaccessibility of minerals from blackberries, raspberries, blueberries and strawberries. J Food Compos Anal. https://doi.org/10.1016/j.jfca.2016.12.001

Pohl P, Stecka H, Greda K, Jamroz P (2012) Bioaccessibility of Ca, Cu, $\mathrm{Fe}, \mathrm{Mg}, \mathrm{Mn}$ and $\mathrm{Zn}$ from commercial bee honeys. Food Chem 134: 392-396

Pohl P, Szymczycha-Madeja A, Stelmach E, Welna M (2016) Differentiation of roasted and soluble coffees through physical fractionation of selected essential and nonessential metals in their brews and exploratory data analysis. Talanta 160:686-693

Powell JJ, Burden TJ, Thompson RPH (1998) In vitro mineral availability from digested tea: a rich dietary source of manganese. Analyst 123: $1721-1724$
Romarís-Hortas V, García-Sartal C, del Carmen Barciela-Alonso M, Domínguez-González R, Moreda-Pińeiro A, Bermejo-Barrera P (2011) Bioavailability study using an in-vitro method of iodine and bromine in edible seaweed. Food Chem 124:1747-1752

Shen L, Robberecht H, Van Dael P, Deelstra H (1995) Estimation of the bioavailability of zinc and calcium from human, cow's, goat, and sheep milk by an in vitro method. Biol Trace Elem Res 49:107-118

Souza LA, Souza TL, Santana FB, Araujo RGO, Teixeira LSG, Santos DCMB, Korn MGA (2018) Determination and in vitro bioaccessibility evaluation of $\mathrm{Ca}, \mathrm{Cu}, \mathrm{Fe}, \mathrm{K}, \mathrm{Mg}, \mathrm{Mn}, \mathrm{Mo}, \mathrm{Na}, \mathrm{P}$ and $\mathrm{Zn}$ in linseed and sesame. Microchem J 137:8-14

Stelmach E, Pohl P, Szymczycha-Madeja A (2014) Evaluation of the bioaccessibility of $\mathrm{Ca}, \mathrm{Fe}, \mathrm{Mg}$ and $\mathrm{Mn}$ in ground coffee infusions by in vitro gastrointestinal digestion. J Braz Chem Soc 25:19931999

Stelmach E, Pohl P, Szymczycha-Madeja A (2016) A simplified determination of total concentrations of $\mathrm{Ca}, \mathrm{Fe}, \mathrm{Mg}$ and $\mathrm{Mn}$ in addition to their bioaccessible fraction in popular instant coffee brews. Food Chem 197:388-394

Szentmihayli K, Hajdu M, Fodor J, Kotai L, Blazovics A, Samogyi A, Then M (2006) In vitro study of elements in herbal remedies. Biol Trace Elem Res 114:143-150

Szymczycha-Madeja A, Welna M, Pohl P (2015) Solubility and bioaccessibility of $\mathrm{Ba}, \mathrm{Ca}, \mathrm{Cr}, \mathrm{Cu}, \mathrm{Fe}, \mathrm{Mg}, \mathrm{Mn}, \mathrm{P}, \mathrm{Sr}$ and $\mathrm{Zn}$ in slim coffee by in vitro gastrointestinal digestion. J Braz Chem Soc 26:17811789

Szymczycha-Madeja A, Pohl P, Welna M, Stelmach E, Jedryczko D (2016) The evaluation of the suitability of different alternative sample preparation procedures prior to the multi-elemental analysis of brews of ground roasted and instant coffees by FAAS and ICP OES. Food Res Int 89:958-966

Vitali D, Vedrina Dragojevic I, Sebecic B (2008) Bioaccessibility of Ca, $\mathrm{Mg}, \mathrm{Mn}$ and $\mathrm{Cu}$ from whole grain tea-biscuits: impact of proteins, phytic acid and polyphenols. Food Chem 100:62-68

Wolters MGE, Schreuder HAW, van den Heuvel G, van Lonkhuijsen HJ, Hermus RJJ, Voragen AGJ (1993) A continuous in vitro method for estimation of the bioavailability of minerals and trace elements in foods: application to breads varying in phytic acid content. Br J Nutr 69:849-861

Zhou Y, Gao X, Wu C, Wy Y (2014) Bioaccessibility and safety assessment of trace elements from decoction of "Zhebawei" herbal medicines by in vitro digestion method. J Trace Elem Med Biol 28:173178 